\title{
Psychological distress and problem drinking
}

\author{
Emmanouil Mentzakis ${ }^{\mathrm{a},},{ }^{,}$, Bayard Roberts ${ }^{\mathrm{b}}$, Marc Suhrcke $^{\mathrm{c}}$ and Martin McKee ${ }^{\mathrm{b}}$

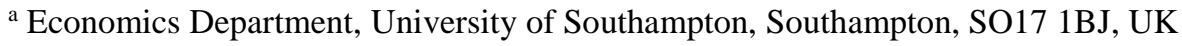 \\ ${ }^{b}$ European Centre on Health of Societies in Transition, Faculty of Public Health and Policy, London School of \\ Hygiene and Tropical Medicine, London, UK. \\ ${ }^{c}$ Centre for Health Economics, University of York, York, YO10 5DD, UK
}

\begin{abstract}
We examine the influence of harmful alcohol use on mental health using a flexible two-step instrumental variables approach and household survey data from nine countries of the former Soviet Union. Using alcohol advertisements to instrument for alcohol, we show that problem drinking has a large detrimental effect on psychological distress, with problem drinkers exhibiting a $42 \%$ increase in the number of mental health problems reported and a $15 \%$ higher chance of reporting very poor mental health. Ignoring endogeneity leads to an underestimation of the damaging effect of excessive drinking. Findings suggest that more effective alcohol polices and treatment services in the former Soviet Union may have added benefits in terms of reducing poor mental health.
\end{abstract}

Keywords: alcohol abuse; mental health; advertising; instrumental variables; causality JEL: C36, I18

PsycINFO: 3365; 2990; 3940

\section{Highlights}

- Causal links between harmful alcohol use and mental health are examined

- Problem drinking is instrumented by number of advertisements of alcoholic products

- Problem drinkers are up to $15 \%$ more likely to report very poor mental health

- Ignoring endogeneity underestimates the effects of alcohol on psychological distress

- Interventions to reduce harmful drinking would additionally benefit mental health

\footnotetext{
* Corresponding author: Economics Department, University of Southampton, University Rd., Southampton, SO17 1BJ, UK. Email: E.Mentzakis@ soton.ac.uk
} 


\section{Introduction}

There is growing evidence of the association between harmful alcohol use and mental disorders, including depression, anxiety, post-traumatic stress disorder, phobias and personality disorders (Conway, Compton, Stinson, \& Grant, 2006; Farrell, et al., 2001; Kessler, Crum, Warner, Nelson, Schulenberg, \& Anthony, 1997; Rehm, et al., 2010; Sacco, Bucholz, \& Spitznagel, 2009). However, establishing causal pathways between alcohol consumption and poor mental health is complex, with some studies indicating harmful alcohol use can increase the risk of mental disorders (Boden \& Fergusson, 2011; Hasin \& Grant, 2002; Wang \& Patten, 2002), while others suggest that individuals with poor mental health are more prone to harmful alcohol use as a negative form of coping with the effects of the symptoms of mental disorders (B. F. Grant \& Hartford, 1995; V. V. Grant, Stewart, \& Mohr, 2009; Kuo, Gardner, Kendler, \& Prescott, 2006). Such reverse causality has been once previously examined through a structural equation model using New Zealand data (Fergusson, Boden, \& Horwood, 2009), where alcohol abuse increased the risk of depression. However, the small sample size and the lack of exclusion restrictions implied strong assumptions for identification suggesting caution in drawing inferences. The need for further research in order to clarify the nature of this causal link was also suggested by a recent meta-analysis (although they argued that a causal effect from alcohol to increased risk of depression was more likely) (Boden \& Fergusson, 2011).

In this study we employ an instrumental variables (IV) approach to address the question of causality, taking advantage of a unique dataset with information on individuals and their local community (i.e. neighbourhood) characteristics in 9 countries of the former Soviet Union (fSU). The fSU is important in this respect as it has the highest levels globally of harmful alcohol use and its subsequent health effects and burden of disease (Lim, et al., 2012; WHO, 2011b). Alcohol consumption was traditionally high in the majority of fSU countries, but increased substantially after the collapse of communism (Krasovsky, 2009; Nemtsov, 2011; Pomerleau, McKee, Rose, Haerpfer, Rotman, \& Tumanov, 2005). This has been linked to the social stress, uncertainty and impoverishment resulting from the collapse of communism, the growth in the production of illicit spirits and surrogate alcohols, and sharp declines in vodka prices during the deregulation of the alcohol industry (Moskalewicz \& Simpura, 2000; Nemtsov, 2011; Stuckler, King, \& McKee, 2009; Treisman, 2010). The evidence for high levels of stress is seen in the steep increases in male 
suicide rates and mental disorders that followed the collapse of the Soviet Union (Andreev, Pridemore, Shkolnikov, \& Antonova, 2008; Brainerd, 2001; Leon \& Shkolnikov, 1998; Pietila \& Rytkonen, 2008; Plavinski, Plavinskaya, \& Klimov, 2003; Tomkins, et al., 2012; UNICEF, 2001; WHO/Europe, 2013). Even now, post-Soviet societies continue to be characterised by many established risk-factors for poor mental health, such as impoverishment, social instability, isolation and low levels of social welfare, and generally poor quality mental health services (Jenkins, Klein, \& Parker, 2005; McDaid, Samyshkin, Jenkins, Potasheva, Nikiforov, \& Ali Atun, 2006; Roberts, Abbott, \& McKee, 2012; Tomov, Van Voren, Keukens, \& Puras, 2007; UNDP, 2011). However, precise evidence on the burden of mental ill-health in the region remains limited (Fister \& McKee, 2005; Jenkins, et al., 2005).

While the severe physical health effects of harmful alcohol use in the countries of the former Soviet Union have been described in detail (Leon, Saburova, Tomkins, McKee, \& Shkolnikov, 2007; Nicholson, Bobak, Murphy, Rose, \& Marmot, 2005; Shkolnikov, McKee, \& Leon, 2001; Zaridze, et al., 2009), to the best of our knowledge, no studies have examined the relationship between mental health and harmful alcohol use in the fSU (Roberts, et al., 2012; WHO, 2011a). The only related paper appears to be a study looking at the links between alcohol consumption and life satisfaction and happiness (Mentzakis, Suhrcke, Roberts, Murphy, \& McKee, 2013). However, the use of such more general well-being questions has been critically received in the literature due to problems related to single item measures, reporting heterogeneity and validity (Carifio \& Perla, 2007; Kahneman \& Krueger, 2006).

The objective of this paper is to examine the influence of harmful alcohol use on mental health, while taking care in addressing the endogenous relationship between alcohol consumption and poor mental health through the use of instrumental variable analysis. Most notably, our findings suggest that, consistent with a reverse causality bias, ignoring endogeneity significantly underestimates the effects of alcohol on psychological distress. Section 2 presents the underlying econometric model, Section 3 describes the data and the instrument used, Section 4 presents the results, while Section 5 presents the discussion and concluding remarks.

\section{Econometric model}

Given the framework discussed in the introduction, we assume that individuals maximize a simple utility function, $U=f(H(A), A(H), X)$. Excessive drinking, $A$, (defined using a standard 
instrument to measure problem drinking, see Section 3.1) enters the utility directly (albeit not necessarily with a negative sign as it can have both detrimental and positive effects, e.g. hampering and helping e.g. social interaction) and indirectly (through its effect on the individual's mental health). However, problem drinking is itself a function of health as drinking is often a form of selfmedication or self-harm (Brower, Aldrich, Robinson, Zucker, \& Greden, 2001; Tomasson \& Vaglum, 1996), which implies that the effects of problem drinking on health are confounded with the effects of health on problem drinking and disentangling the two in a simple regression is not possible (i.e. reverse causality).

Assuming that mental health has a continuous, fully observable representation, the initial econometric model is

$H_{i}=x_{i} \beta+\delta A_{i}+\varepsilon_{i}$

$H_{i}$ is individual mental health, $A_{i}$ is our indicator of problem drinking, $x_{i}$ are a number of relevant covariates, including demographics and socio-economic characteristics, while $\varepsilon_{i}$ is the error term. From the utility function $H_{i}$ and $A_{i}$ are simultaneously determined and an instrument, relevant ( $\left.\operatorname{Cov}\left(z, A_{i}\right) \neq 0\right)$ and exogenous $\left(\operatorname{Cov}\left(z, \varepsilon_{i}\right)=0\right)$, is necessary for the model to be identified and consistently estimated (Angrist \& Pischke, 2008).

Assuming that the observed $A_{i}$ is the realisation of an unobserved latent problem drinking variable, $A_{i}^{*}$, which is a function of an exogenous factor, $z_{i}$ - our instrument - we have

$A_{i}^{*}=\gamma z_{i}+u_{i} \quad$ with $A_{i}=\left\{\begin{array}{lc}1 & \text { if } A_{i}^{*}>0 \\ 0 & \text { otherwise }\end{array}\right.$

In this study we instrument problem drinking with the amount of alcohol related marketing an individual comes into contact with, as implied by the number of alcohol advertisement present in the individual's local community (the validity of the instrument will be discussed in the next section). Given that we have a binary indicator for the first stage (i.e. problem drinking) the above model can be estimated in two steps, by taking the generalised residual of the first stage (probit) equation and adding it into the reduced form equation of interest. 
However, the assumption until now is that $H_{i}$ can be treated as a fully observed continuous variable. We relax this assumption by assuming that the observed $H_{i}$ is the discrete realisation of a latent variable, $H_{i}^{*}$, which is a linear function of $x_{i}$ and $A_{i}$.

$H_{i}^{*}=x_{i} \beta+\delta A_{i}+v_{i}$, where $H_{i}=j$ if $k_{j-1}<H_{i}^{*} \leq k_{j}$ for $j=1, \ldots, J$

This gives rise to the ordered probit specification where $A_{i}$ is an endogenous regressor that needs to be instrumented (Roodman, 2011), $k_{j}$ are cut-offs that need to be estimated along with the $\beta$ and $\delta$, while for identification the variance is normalised to 1 . Instrumentation follows as previously in a two-step estimator, with the first step being a simple probit and the reduced form an ordered probit. Note that in the two-step estimator, the standard errors of the second step need to be corrected.

The ordered probit model, while only using the ordinal information of the $H_{i}$ variable, still assumes constant cut-offs. In other words, it assumes that the effect (slope coefficient) of the covariates on interest (both endogenous and exogenous) are the same across the distribution of $H_{i}$, i.e. parallel lines assumption (Terza, 1985). This is similar to having $J-1$ probit equations (where $H_{i}$ is dichotomised for every value, e.g. 1 if $H_{i}=1$ and 0 if $H_{i}>1$; then 1 if $H_{i} \leq 2$ and 0 if $H_{i}>$ 2 and so on) where the parameters $\beta$ and $\delta$ are constrained to be equal. This constraint does not allow for heterogeneity of effects, i.e. a different effect of alcohol on those with good mental health than those with poor mental health status. In order to relax this constraint, we make the cut-offs a linear function of the covariates (i.e. a generalised ordered probit) while instrumenting for $A_{i}$ in a two-step estimator.

$\tau_{i j}=k_{j}+g_{i} \gamma_{j}$

where $\mathrm{g}_{\mathrm{i}}$ is a vector of individual characteristics/variables, that can be the same or different from the those in $x_{i}$ and $z_{i}$. Note however, for those covariates that are common in eq. 2,3 and 4 , the parameters of eq. 3 cannot be separately identified, $\beta_{\mathrm{j}}=\beta-\gamma_{\mathrm{j}}$, although its properties still hold. A Hausman test indicates whether the restriction imposed by the simple ordered probit is valid or it needs to be relaxed in favour of the generalised specification. 
Following estimation due to the normalisation of the scale (contrary to the linear model) the coefficients of the reduced form equation (ordinal model) do not have a quantitative interpretation (as they are on the scale of the latent variable). Marginal effects are computed as first derivatives for the continuous variables and as discrete changes for binary indicators (i.e. the problem drinking variable).

\section{Data}

Data from the Health in Times of Transition (HITT) study (http://www.hitt-cis.net/) collected in 2010/11 are used. This was a follow-up to the 2001 Living Conditions, Lifestyles and Health (LLH) study. Information on a socio-economic, demographic, health and lifestyle characteristics was collected using cross-sectional surveys of 18000 individuals (aged 18+) in 9 fSU countries (Armenia, Azerbaijan, Belarus, Georgia, Kazakhstan, Kyrgyzstan, Moldova, Russia, and Ukraine). Multistage random sampling with stratification by region and rural/urban settlement type was used, while within each primary sampling unit (approximately 100-200 per country), households were selected by standardized random route procedures (for more on the surveys see (Balabanova, Roberts, Richardson, Haerpfer, \& McKee, 2012; Gilmore, et al., 2004).

The HITT study additionally collected community level information alongside individual questionnaires. Community profiling was undertaken by randomly sampling 300 of the sampling units used for the main household survey. Trained data collectors completed structured observation forms that captures a range of community characteristics related to health and lifestyle. The community profiling methodology is based upon that used in a related study and has been shown to be valid and reliable (Chow, et al., 2010). Community profiles are merged with individual-level data from respondents living in these 300 communities. The increased level of information this affords comes at a cost in terms of sample size (in the analysis we test for sensitivity of findings to sample size). Equality of mean sample values for all variables used in the analysis is formally tested using the Welch approximation of the t-test (for more see Tables).

\subsection{Mental health outcome and problem drinking indicator}

As a measure of mental health, $H_{i}$, we utilise an instrument developed specifically for this region in the earlier LLH study, consisting of a set of 14 items on psychological distress symptoms, as 
previously described (Cockerham, Hinote, \& Abbott, 2006; Roberts, Abbott, \& McKee, 2010; Roberts, et al., 2012). Respondents were asked if they had recently experienced (yes/no) any of 14 symptoms: 1) inability to concentrated, 2) insomnia, 3) feeling constantly under strain, 4) feeling you could not overcome your difficulties, 5) not enjoying daily activities, 6) losing confidence in yourself, 7) often shaking or trembling, 8) frightening thoughts coming into your mind, 9) frightening thoughts coming into your mind, 10) feelings of stress, 11) feeling lonely, 12) feeling dissatisfied with work, 13) feeling an impossibility to influence things, 14) feeling that life is too complicated.

The responses of each individual are summed and the final score can take values between 0 (experiencing no psychological distress) and 14 (maximum psychological distress) (Table 1). The internal reliability of the psychological distress instrument was good (Cronbach alpha $=0.82)$ with these data and the instrument has been previously used successfully in other studies (Hinote, Cockerham, \& Abbott, 2009; Roberts, et al., 2010). Given the ordinal nature of this variable and the very long right tail, we collapse some of the rarer values. This is done to contain the number of categories to be modelled and to facilitate interpretation of results, while it should not affect our findings. Figure 1 presents country-specific and overall histograms of the collapsed variable.

Our indicator of problem drinking, $A_{i}$, is taken from the CAGE questionnaire (Ewing, 1984), which is a widely used method of screening for problem drinking (Kitchens, 1994). CAGE consists of four questions: 1) Have you ever felt you needed to Cut down on your drinking?; 2) Have people Annoyed you by criticizing your drinking?; 3) Have you ever felt Guilty about drinking?; 4) Have you ever felt you needed a drink first thing in the morning (Eye-opener) to steady your nerves or to get rid of a hangover. Each positive answer scores one point with the tests taking values between 0 and 4. Figure 2 presents country-specific and overall histograms of the original CAGE scores. Validation against laboratory tests indicated that scores $\geq 2$ had a sensitivity of $93 \%$ and a specificity of 76\% for the identification of problem drinkers (Bernadt, Taylor, Mumford, Smith, $\&$ Murray, 1982). Table 2 present the proportions of problem drinking by country and overall for the sample.

\subsection{Estimation covariates}


Our estimates control for a number of demographic and socio-economic factors common in wellbeing analyses, including age, gender, marital status, employment, household size, employment status, economic situation and health (Table 3 shows sample descriptive statistics and definitions). Self-assessed financial situation ${ }^{1}$ and an asset index ${ }^{2}$ are used to capture economic status as previous work has found both income and wealth to matter (McBride, 2001; Mentzakis \& Moro, 2009; Roberts, et al., 2012b). Estimations also include country fixed effects capturing country specific alcohol behaviour or policies. ${ }^{3}$ Furthermore, such effects accommodate constant withincountry reporting heterogeneity in the CAGE and/or mental health variables, as populations in different countries may use different reference points when reporting self-perceived measures (Jurges, 2007).

\subsection{Instrument and instrument validity}

For the instrumentation of the problem drinking indicator the number of advertisements of alcoholic products in the individual's local community is used. ${ }^{4}$ This included all alcohol advertisements that were visible from the street, include those on billboards, pasted on shop windows, bus shelters, restaurants, cafes, bars or other establishments or places. Table 4 presents sample descriptive statistics for the instrument by country and overall.

For the IV methodology to produce consistent estimates the instrument must be correlated directly with problem drinking but not correlated with psychological distress. The validity of such an instrument must be justified theoretically and empirically (Cameron \& Trivedi, 2005). There is a large literature on how advertising increases alcohol consumption (Saffer \& Dave, 2006; Snyder, Milici, Slater, Sun, \& Strizhakova, 2006). Using data from 17 countries, Saffer (Saffer, 1991)

\footnotetext{
1 "How would you describe the economic situation of your household at present time?" with five potential response categories ranging from Very bad to Very good.

${ }^{2}$ Composed of responses to 10 questions on possessing certain objects or comforts (i.e. fridge, TV, washing machine (not automatic), mobile telephone, computer, car produced before 2005, automatic washing machine, home cinema, dishwasher and car made since 2005), assigning a value of one for each affirmative response and summing up the 10 responses for each individual the wealth index takes values ranging from 0 to 10 .

${ }^{3}$ Due to the community level nature of our instrument, community fixed effects cannot be included.

${ }^{4}$ Within each community selected, data collectors (two per community) chose a starting point by selecting a prominent land mark (e.g. major road intersection, bus/train station, market, post office, crossroads in the village centre) and would then select and follow a walking route (approximately 1 kilometre) systematically completing the profiling form and take accompanying photographs. In villages, this route would be the entire village. In towns or cities, it involved a walk along the main shopping streets and residential areas.
} 
found that countries with bans on alcohol advertising have significantly lower alcohol consumption compared to countries with no or partial bans. Another longitudinal study (Anderson, de Bruijn, Angus, Gordon, \& Hastings, 2009) similarly concluded that alcohol advertising and promotion increases the likelihood of starting to drink, as well as of increases in consumption. However, some studies have found small or insignificant correlations between alcohol advertising and alcohol consumption (Blake \& Nied, 1997; Nelson, 1999; Ogborne \& Smart, 1980). Saffer and Dave (Saffer \& Dave, 2002) explain the differing findings by means of an economic model which distinguishes between industry level and firm level advertisements, concluding that alcohol advertising bans do decrease alcohol consumption.

A systematic review (Smith \& Foxcroft, 2009) of seven cohort studies found an association between exposure to alcohol advertising or promotional activity and subsequent alcohol consumption, while a meta-analysis review of 322 estimates of advertising expenditure elasticities reported a positive effect of advertising on alcohol consumption (Gallet, 2007). Another systematic review of 13 longitudinal studies found a consistent positive association between advertising and alcohol consumption and, based on the strength of the association, the consistency of findings across numerous studies, the temporality of exposure and drinking behaviours observed and doseresponse relationships concluded that alcohol advertising and promotion increase the likelihood that adolescents will start to use alcohol, and to drink more if they are already using alcohol (Anderson, et al., 2009). Finally, an evidence synthesis on the effectiveness of policies in reducing the harm caused by alcohol argues that banning alcohol advertising is a highly cost-effective strategy, especially in settings where alcohol poses a substantial public health problem, e.g. countries of the European region with low child mortality but high adult mortality (i.e. Russia, Ukraine etc.) (Anderson, Chisholm, \& Fuhr, 2009).

Following Angrist and Pischke's (Angrist \& Pischke, 2008) suggestion we explore alternative functional forms for the instrument, namely the square of the number of alcohol advertisements. The rationale behind either the level or the square of advertisements is identical but they imply different rates of effect, with the square dampening the effect of advertising on drinking for low numbers of advertisements and allowing for increasing effects as the numbers grow. Figure 3 plots the fitted values from linear probability models of the effect of number of advertisements on problem drinking to show differences in the implied relationship; adjusted $R^{2}$ from the regressions are also given. Given that both functional forms of the instrument are 
identical in their theoretical background, we rely on empirical analysis to decide on the preferred one (including a sensitivity analysis for differences arising from the choice of forms).

\subsection{Instrument exogeneity}

While the correlation between alcohol advertisements and drinking is not only intuitive but also supported by the literature, there is little reason to suspect that the number of advertisements will have a direct effect on the psychological distress of the individuals. However, despite the lack of any evidence in the literature, some potential indirect avenues could be identified. The first might be through a correlation with number of shops selling alcohol which is in turn correlated with wellbeing through its effects on violence. A review on the spatial relationship between outlet density and rates of violence found that most studies reported a significant positive relationship (Livingston, et al., 2007), while another study found the density of off-premise alcohol outlets to be related to the rate of alcohol use disorders (Livingston, 2011). Finally, a review of forty-four studies linked density of alcohol outlets to damage from alcohol, with damage defined to include both trauma (intentional and unintentional causes) but also social problems (Popova, Giesbrecht, Bekmuradov, \& Patra, 2009). Looking at the link between alcohol advertisements and alcohol shops in our sample we find a strong correlation - an $R^{2}$ of about $18 \%$ in a linear regression of shops on advertisements. To avoid the risk that the association between advertisements and mental health through the density of shops might bias our estimations, we condition on the number of alcohol shops in the local community in the regression. Table 5 gives descriptive statistics of the number of shops by country.

Another possible avenue is through marketing campaigns by the alcohol companies targeted at individuals who are more prone to risky/unhealthy behaviours. While it is not easy to test this hypothesis, we can test whether individual's mental health explains any systematic variation in the number of advertisements present in their local community and we do this by running a negative binomial model of the number of advertisements on psychological distress. Controlling for age, gender and being married, there is no significant association between health and number of advertisements. $^{5}$

\footnotetext{
${ }^{5}$ Running an ordered probit to test whether alcohol advertisements (i.e. independent variable) explain any variation in psychological distress (i.e. dependent variable) we also fail to find any significant association.
} 
Further, under the assumption that the population prone to risky behaviours has been identified and subjected to targeted marketing, we test if (a) the number of tobacco advertisements explains alcohol advertisements and (b) the number of tobacco advertisements can be used to spuriously instrument for problem drinking. Regarding (a) controlling for tobacco and alcohol outlets there is no link between the two types of advertisement and similarly for (b) using tobacco advertisements as an instrument performs extremely poorly, showing no statistical power (i.e. Ftest $=0.27$ ).

This lack of association between number of alcohol advertisements and mental health along with the inclusion of alcohol shops in our regression equation and the large number of observable characteristics, gives us confidence in the exogeneity of our instrument.

\subsection{Estimation strategy and robustness tests}

Taken together, we estimate three linear models (using OLS) - one for the full sample, one for the restricted sample and one with the restricted sample controlling for number of alcohol shops. Comparisons between the full and restricted sample estimations act as informal sample selection tests or as sensitivity tests of our results to sample size. Equality of coefficients is formally tested with Wald tests. For the IV specifications we estimate two specifications, one treating mental health as a continuous (Maddala, 1983) and one treating it as an ordinal variable (Roodman, 2011) (for both the first stage is binary, i.e. detected problem drinking or not). Using an LR-test we examine whether the parallel line assumption of the standard ordered probit is too restrictive and the generalised model should be preferred. Marginal effects are calculated for the preferred specification. Further, we test whether the level or the square of the number of alcohol advertisements performs statistically better in the first stage of the IV estimations, while we finally assess whether collapsing the ordinal mental health variable from 12 to 6 levels affects our findings. All models use robust standard errors, clustered at the community level. All analysis is performed in Stata/MP 12.1. ${ }^{6}$

\section{Results}

\footnotetext{
${ }^{6}$ For the estimations that Stata built-in capabilities are not available we use user written routines, namely -cmp- by David Roodman (Roodman, 2011) and -gologit2- by Richard Williams (Williams, 2006).
} 


\subsection{Descriptive statistics}

Summary statistics for mental health are given in Table 1. All 14 symptoms are quite frequent, with insomnia, exhaustion or fatigue and stating that life is too complicated reported by about $40 \%$ of respondents. The two least common symptoms were losing self-confidence and nervous shaking or trembling. On average, respondents report suffering slightly more than 3 symptoms, while comparisons between the restricted and full sample show no differences, both when comparing item responses and overall scores. Table 2 reports on the prevalence of problem drinking using the CAGE instrument, with about $13 \%$ and $14.6 \%$ of the respondents coded as suffering for the full and restricted sample, respectively. Looking at country level summaries, Armenia and Azerbaijan report levels well below the average, whereas Belarus and Moldova are located above the average. Differences between full and restricted sample averages are not statistically significant.

Table 3 presents descriptive statistics for socio-economic and demographic indicators included in the regressions. Forty-four percent are male, with age ranging from 18 to 90 years and an average of 44 , while $62 \%$ are married and $21 \%$ single. Average household size is 3.6 individuals and with less than one child per household. Twenty-eight percent have had some higher education (completed and non- completed), $46 \%$ are employed and $20 \%$ unemployed. Twenty-two percent of respondents stated that they believed they were in a good or very good financial position, while the mean value for the wealth index was 4.2. Finally, $41 \%$ indicated that they had good or very good health, with $74 \%$ and $66 \%$ stating that they can easily or fairly easily walk 1 kilometre or

climb two or three flights of stairs without getting out of breath. Again, differences between full and restricted sample are minimal.

With respect to our instrument, there are significant inter- and intra- (i.e. local community) country differences (Table 4). The overall average of advertisements for alcoholic drinks in each local community is 6.8 , with a standard deviation of about 8.7 implying significant variation. There are also large variations among countries, with Moldova and Ukraine recording the highest figures and Azerbaijan and Belarus the lowest. Moving from the full to the restricted sample makes little difference in the advertisement counts recorded. The fact that Azerbaijan is predominantly Muslim and Belarus has a semi-communist style of government resulting in few adverts generally might explain the low numbers of alcohol advertisements for these countries. 
We find a similar overall average of about 7 alcohol shops per local community (Table 5), but again with considerable intra-country variation (s.d. =5) and little cross-country differences. Comparing full and the restricted sample averages, differences not statistically different. .

\subsection{Robustness/sensitivity checks and preliminary tests}

Before we continue to discuss our findings or draw inferences on the direction of the causal relationship between problem drinking and mental health we must discuss some of the estimation choices made. Firstly, while descriptive statistics showed no difference between full and restricted estimation samples, further formal testing of this hypothesis in a regression setting is required. The first two columns of Table 6 present simple OLS results from the two samples. Looking at the coefficients and the adjusted $R^{2}$ of regressions there is little that separates them. Computing Wald tests of equality of coefficients between the two columns we find that all are statistically the same, with the exception of Unemployed (p-value for the difference is 0.03), which, however, is not of concern as its effect is insignificant in the overall estimation.

Secondly, testing the parallel line assumption of the ordered probit discussed above, we find that relaxing the assumption in the two-step IV estimator and allowing the effect of problem drinking to vary by level of mental health does not lead to an improved fit (LR-test $=5.08$, $p$-value $=0.41$ ). As such we adopt the standard ordered probit specification as the preferred model.

Thirdly, we compare the fit of the level and square of the number of alcohol advertisements as instruments and the results obtained, respectively. The easiest way to do this is by looking at the F-test of a first-stage linear probability regression model of the effect of alcohol advertisements on problem drinking. Estimating a linear probability model, though not the most efficient, is still consistent and unbiased (Angrist \& Pischke, 2008; Baum, Schaffer, \& Stillman, 2012). While both functional forms of the instrument perform well and pass conventional tests - level F-test $=26.7$ and square F-test=45.4 - and both models have similar goodness-of-fit values - adjusted- $R^{2}=0.11$ and 0.12 , respectively - the statistics slightly favour the squared form. ${ }^{7}$ Figure 3 presents the relationship estimated above. Although, when presenting the estimation results below, we adopt

\footnotetext{
${ }^{7}$ Results for the first stage and the main equation are comparable when the quadratic functional form for the instrument is used.
} 
the square functional form, the two models give almost identical results (see Section 4.3 for further details).

Finally, collapsing the 14 ordinal mental health levels to 6 does not alter our findings. ${ }^{8}$

\subsection{Estimation results}

Estimations results are given in Table 6. We first consider the three OLS models. As discussed above, no significant variations are observed when the sample size changes. Comparing columns 1 and 2, despite the substantial reduction in sample size, both estimations seem to fit equally well, with the estimated parameters largely comparable and with no indication of consistent up- or downward bias. Further, column 3 adds the control for number of alcohol shops, which we saw (in Section 3.4) was significant in the univariate model; it remains positive but only marginally significant.

Moving on to the two-step IV estimation, the first step probit is shown in column 4. The square of the number of alcohol advertisements is highly significant and positive, implying an increased probability of problem drinking with increasing number of advertisements, which is necessary to determine the validity of our instrument and mitigate concerns about weak identification. Controlling for the number of advertisements, the number of alcohol shops is now statistically insignificant.

Turning to the second stage of the IV specifications, we estimate one model that treats mental health as a continuous (column 5) and one that treats it as an ordinal variable (column 6). Although not directly comparable as the coefficients of the ordinal model are estimated up to scale, we also present marginal effects for the ordered probit in Table 7. Both models show that those identified as problem drinkers report increased psychological distress. Once endogeneity is taken into account, the magnitude of the estimated coefficient increases, implying an underestimation of the effect for the naive OLS specification (comparison of columns 3 and 5). Namely, an increase of 1.2 units from the linear IV model implies a $42 \%$ increase in the number of mental problems reported (or 0.6 of a standard deviation) for the average individual who is identified as a problem drinker, compared to a $21 \%$ increase (or 0.28 of a standard deviation) for the naive OLS model. As a result of the IV estimation we also, as expected, observe inflated standard errors for the causal

\footnotetext{
${ }^{8}$ Results are not presented but are available upon request.
} 
model. Looking at the marginal effects of the ordinal model, we observe a change in the sign for mental health levels of 3 or more, implying that problem drinkers are less likely to report distress at a score of two or less. Specifically, problem drinking increases the probability of reporting a score of 4 on the distress scale by $2.5 \%$, a score of 5 to 6 by $6 \%$ and a score of 7 to 14 by $15 \% .{ }^{9}$

Looking at the rest of the estimated parameters, conditional on problem drinking, the number of alcohol shops has a marginally significant and positive effect, implying lower mental health, with males being more likely to report significantly less psychological distress compared to females, and age having an inverted U-shape effect that is, however, statistically insignificant. Those married report better mental health compared to the reference category of being single, whereas there is no significant association between mental health and higher education, larger household sizes and number of children. Compared to those inactive or retired, employed individuals report significantly less distress, although those currently unemployed appear to also have improved scores. Yet this finding is only significant at the $10 \%$ significance level and not consistent across specifications. Wealthier individuals (measured either through the financial situation question or the asset index) are also less psychologically distressed. Finally, as expected, all physical health indicators are negative and highly significant with large magnitudes, implying healthier individuals reporting reduced psychological distress.

\section{Conclusions}

Using a flexible two-step instrumental variables approach we have attempted for the first time to examine the causal links between problem drinking and psychological distress for a sample of individuals in the fSU. Problem drinking is measured as a score on the CAGE questionnaire and is instrumented by the number of advertisements of alcoholic products in the local community of the individuals. Both theoretically and empirically, our instrument performs well, while a number of checks and sensitivity tests ensure that our sample selection does not bias our estimates. Overall, we find that problem drinking has a large and significant detrimental effect on psychological distress, with problem drinker exhibiting a $42 \%$ increase in the number of mental health problems reported and a $15 \%$ higher chance of reporting very poor mental health. Further, we find that

\footnotetext{
9 The corresponding figure from the IV estimation using the level of alcohol ads as an instrument are $2.9 \%, 7 \%$ and $18 \%$. Full estimation results are available upon request.
} 
ignoring endogeneity leads to an underestimation of the damaging effect of excessive drinking. Such underestimation is the result of negative covariance between the error term and the excessive drinking indicator, which is consistent with the reverse causality bias of drinking as a way of selfmedication.

Our findings support the few existing studies, cited earlier, on the detrimental effect of harmful alcohol on mental health (Hasin \& Grant, 2002; Wang \& Patten, 2001; Wang \& Patten, 2002), including those that have used structural equation modelling (Fergusson, et al., 2009; Fergusson, Boden, \& Horwood, 2011). Our results also support findings of a systematic review that indicated that increasing use of alcohol increases risk of depression (Boden \& Fergusson, 2011). Several mechanisms have been postulated to explain this association. First, alcohol use and mental disorders may be linked by genetic factors relating to neurotransmitter functioning which increase the risk of mental disorders in the presence of harmful alcohol use. Second, harmful alcohol use may cause metabolic changes that increase the risk of mental disorders. Thirdly, indirect effects by which harmful alcohol use may negatively impact on an individual's socioeconomic circumstances, which may then lead to worse mental health are not directly estimated in our model but their possibility suggests that our figures are conservative estimate of the total effect of problem drinking on mental health.

Other findings within our results are also consistent with theory and with existing mental health evidence, adding to the convergent and theoretical validity of our results (Dave \& Saffer, 2008; Dolan, Peasgood, \& White, 2008). These include women generally reporting worse mental health than men (Cockerham, et al., 2006; Gold, 1998; Patel, Araya, de Lima, Ludermir, \& Todd, 1999; WHO, 2000), marriage being protective of mental health (Kim \& McKenry, 2002; Mentzakis, McNamee, Ryan, \& Sutton, 2012), higher absolute and relative income supporting good mental health (Clark \& Oswald, 1996; Lund, et al., 2010; Mentzakis \& Moro, 2009), and a strong positive link between better physical and mental health (Clark \& Oswald, 2002; Mentzakis, 2011) (although potential adaptation effects cannot be controlled for in our cross-sectional design (Groot, 2000; Heyink, 1993).

Our findings suggest that more effective alcohol polices and treatment services in the region may have added benefits in terms of reducing poor mental health, and studies from other regions have shown that treatment for harmful alcohol use can result in a reduction of symptoms of mental disorders (Baker, et al., 2010; Kelly, Stout, Magill, Tonigan, \& Pagano, 2010). However, despite 
the high levels of harmful alcohol consumption and associated burden of poor mental and physical health, recent government alcohol control policies in the region have been marked by limited ambition, lack of engagement, and fragmentation among key actors, while the larger alcohol producers have become very influential in blocking action (Gil, Polikina, Koroleva, Leon, \& McKee, 2010; Nemtsov, 2011; Roberts, et al., 2012a; WHO, 2011a). While there have been some price controls implemented in Russia on vodka and price controls proposed in Belarus and Ukraine, more concerted action is still urgently required in the fSU, especially given recent evidence that tax policies are equally effective in deterring alcohol consumption for those with high and lower propensity for alcohol use (Dave \& Saffer, 2008). Treatment for harmful drinking also remains outdated (Rechel, Kennedy, McKee, \& Rechel, 2011).

Given that individuals with mental disorders may also use alcohol to self-medicate the mental disorder symptoms (Grant, et al., 2009), a combination of treatments for harmful alcohol use and mental disorders may yield the greatest benefits for those presenting with both disorders. However, mental health services and systems remain limited, and greater attention is also required on risk-factors for poor mental health such as social exclusion and widening socioeconomic inequalities (Bobak, et al., 2006; Brainerd, 2001; Jenkins, et al., 2005; Jenkins, et al., 2010; McDaid, et al., 2006; Roberts, et al., 2012; Tomov, et al., 2007).

We acknowledge some limitations. First, the instrument used to measure psychological distress has undergone limited validation, although it does show good internal reliability, with a Cronbach's alpha score of 0.82 for the combined study sample, and alpha scores ranging from 0.77 in Kyrgyzstan to 0.86 in Armenia, and it has been shown to exhibit good external validity, being responsive to common risk-factors and changes over time (Roberts, et al., 2012). However, given the questions used to construct the CAGE variable one could argue that they plausibly vary with other factors that influence one's mental state. For example, one's response to "Have people annoyed you by criticizing your drinking?" or "Have you ever felt guilty about drinking?" could depend on the sort of people with whom a person associates. ${ }^{10}$ To test the sensitivity our results on this, we repeat the analysis by dropping the two suspect questions from the construction of the

\footnotetext{
${ }^{10}$ An individual will be more depressed if they either choose to or somehow must associate with people who constantly point out one's drinking problem or are depressed or psychologically unstable themselves.
} 
CAGE variable. As expected, the broader characterization of problem drinkers results in a slightly decreased magnitude of the effect ${ }^{11}$ but our conclusions remain the same. ${ }^{12}$

Second, a further argument against the CAGE variable would be the choice of cut-off to identify problem drinkers. To test this we specify three further models with three different cut-off definitions for $\mathrm{CAGE}$ (i.e. $\mathrm{CAGE} \geq 1, \mathrm{CAGE} \geq 3$ and $\mathrm{CAGE}=4$ ) and repeat analysis. As expected for $\mathrm{CAGE} \geq 1$ no significant effect is found as those individuals are less likely to have a drinking problem. For the other two specification the effects are comparable to those reported earlier with slightly stronger magnitudes for $\mathrm{CAGE}=4$ as the drinking problems captured by this definition are more severe.

Third, the lack of longitudinal data prevents us from controlling for unobserved heterogeneity and time-invariant omitted variables that might be important in determining the relationship between mental health and harmful alcohol use. Fourth, in order to perform the necessary IV estimation, the sample size was significantly reduced, which could create selection bias problems. However, tests of equality in the descriptive statistics and estimated parameters between the full and restricted samples show that such problems are unlikely. Although this drop in sample size unfortunately precludes any country specific analysis, we note that the composition, in terms of individual country sizes, between the original and restricted data is very similar, apart perhaps from Russia and Ukraine which are slightly over- and under-represented respectively. Fifth, our small sample also has low statistical power but this is primarily important when one cannot reject the null hypothesis of no effect, which is not the case here. However, such a low sample size could imply a lack of generalisability, although the equality of coefficients discussed above indicates that this should not be a major concern. Finally, our data potentially suffer from problems common to all household surveys of under-reporting of alcohol consumption, exclusion of socially marginalised groups (who are likely to include heavier drinkers) and/or of the heaviest drinkers (who may not be present/willing or able to participate in such surveys), and also possible under-reporting of psychological distress due to the sensitivity and stigma around mental health that is common to almost all settings.

\footnotetext{
${ }^{11}$ Individuals now only need positive answers to two of the four CAGE questions to be classified as problem drinkers. This implies a slightly higher proportion of problem drinkers which is however inclusive of individuals with less of a drinking problem, suggesting a lower overall effect on mental health.

${ }^{12}$ Full estimation results are available upon request.
} 
In conclusion, by applying an instrumental variable approach, we find that problem drinking has a large and significant detrimental effect on psychological distress in the former Soviet Union, with problem drinkers exhibiting a $42 \%$ increase in the number of mental health problems reported and a $15 \%$ higher chance of reporting very poor mental health. We also find that ignoring endogeneity leads to an underestimation of the damaging effect of excessive drinking. The findings suggest that interventions to reduce harmful drinking would have additional benefits for mental health, although further research is needed in this region.

\section{Acknowledgements}

We are grateful to Dean Lillard and an anonymous reviewer for their valuable comments and suggestions and to all members of the Health in Times of Transition Project (HITT) study teams who participated in the co-ordination and organization of data collection for this paper.

\section{Funding}

The HITT Project was funded by the European Union's 7th Framework Programme; project HEALTH-F2-2009-223344. The European Commission cannot accept any responsibility for any information provided or views expressed.

\section{References}

Anderson, P., Chisholm, D., \& Fuhr, D. C. (2009). Effectiveness and cost-effectiveness of policies and programmes to reduce the harm caused by alcohol. The Lancet, 373(9682) 2234-2246.

Anderson, P., de Bruijn, A., Angus, K., Gordon, R., \& Hastings, G. (2009). Impact of alcohol advertising and media exposure on adolescent alcohol use: A systematic review of longitudinal studies. Alcohol and Alcoholism,

Andreev, E., Pridemore, W. A., Shkolnikov, V. M., \& Antonova, O. I. (2008). 2612636; an investigation of the growing number of deaths of unidentified people in Russia. European Journal of Public Health, 18(3), 252-257.

Angrist, J., \& Pischke, J. (2008). Mostly harmless econometrics: An empiricist's companion. Princeton University Press.

Baker, A. L., Kavanagh, D. J., Kay-Lambkin, F., Hunt, S. A., Lewin, T. J., Carr, V. J. et al. (2010). Randomized controlled trial of cognitive-behavioural therapy for coexisting depression and alcohol problems: Short-term outcome. Addiction, 105(1), 87-99.

Balabanova, D., Roberts, B., Richardson, E., Haerpfer, C., \& McKee, M. (2012). Health care reform in the former soviet union: Beyond the transition. Health Services Research, 47(2), 840-864. 
Baum, C. F., Schaffer, M. E. \& Stillman, S. (2012). IVREG2: Stata module for extended instrumental variables/2SLS and GMM estimation.

Bernadt, M. W., Taylor, C., Mumford, J., Smith, B., \& Murray, R. M. (1982). Comparison of questionnaire and laboratory tests in the detection of excessive drinking and alcoholism. The Lancet; Originally Published as Volume 1, Issue 8267, 319(8267), 325-328.

Blake, D., \& Nied, A. (1997). The demand for alcohol in the united kingdom. Applied Economics, 29(12), 1655-1672.

Bobak, M., Pikhart, H., Pajak, A., Kubinova, R., Malyutina, S., Sebakova, H. et al. (2006). Depressive symptoms in urban population samples in russia, poland and the czech republic. British Journal of Psychiatry, 188, 359-365.

Boden, J. M., \& Fergusson, D. M. (2011). Alcohol and depression. Addiction, 106(5), 906-914. from the Alcohol and depression database.

Brainerd, E. (2001). Economic reform and mortality in the former soviet union: A study of the suicide epidemic in the 1990s. European Economic Review, 45, 1007-1019.

Brower, K. J., Aldrich, M. S., Robinson, E. A. R., Zucker, R. A., \& Greden, J. F. (2001). Insomnia, selfmedication, and relapse to alcoholism. American Journal of Psychiatry, 158(3), 399-404.

Cameron, A. C., \& Trivedi, P. K. (2005). Microeconometrics: Methods and applications. New York: Cambridge University Press.

Carifio, J., \& Perla, R. J. (2007). Ten common misunderstandings, misconceptions, persistent myths and urban legends about likert scales and likert response formats and their antidotes. Journal of Social Sciences, 3(3), 106-116.

Chow, C. K., Lock, K., Madhavan, M., Corsi, D. J., Gilmore, A. B., Subramanian, S. V. et al. (2010). Environmental profile of a community's health (EPOCH): An instrument to measure environmental determinants of cardiovascular health in five countries. PLOS ONE, 5(12), e14294.

Clark, A. E., \& Oswald, A. J. (2002). A simple statistical method for measuring how life events affect happiness. International Journal of Epidemiology, 31(6), 1139-1144.

Clark, A. E., \& Oswald, A. J. (1996). Satisfaction and comparison income. Journal of Public Economics, 61(3), 359-381.

Cockerham, W. C., Hinote, B. P., \& Abbott, P. (2006). Psychological distress, gender, and health lifestyles in belarus, kazakhstan, russia, and ukraine. Social Science \& Medicine, 63(9), 2381-2394.

Conway, K. P., Compton, W., Stinson, F. S., \& Grant, B. F. (2006). Lifetime comorbidity of DSM-IV mood and anxiety disorders and specific drug use disorders: Results from the national epidemiologic survey on alcohol and related conditions. Journal of Clinical Psychiatry, 67(2), 247-257.

Dave, D., \& Saffer, H. (2008). Alcohol demand and risk preference. Journal of Economic Psychology, 29(6), 810-831.

Dolan, P., Peasgood, T., \& White, M. (2008). Do we really know what makes us happy? A review of the economic literature on the factors associated with subjective well-being. Journal of Economic Psychology, 29(1), 94-122.

Ewing, J. A. (1984). Detecting alcoholism: The CAGE questionnaire. JAMA: The Journal of the American Medical Association, 252(14), 1905-1907.

Farrell, M., Howes, S., Bebbington, P., Brugha, T., Jenkins, R., Lewis, G. et al. (2001). Nicotine, alcohol and drug dependence and psychiatric comorbidity. results of a national household survey. British Journal of Psychiatry, 179, 432-437. 
Fergusson, D. M., Boden, J. M., \& Horwood, L. J. (2011). Structural models of the comorbidity of internalizing disorders and substance use disorders in a longitudinal birth cohort. Social Psychiatry and Psychiatric Epidemiology, 46(10), 933-942.

Fergusson, D. M., Boden, J. M., \& Horwood, L. J. (2009). Tests of causal links between alcohol abuse or dependence and major depression. Archives of General Psychiatry, 66(3), 260-266. from the Tests of causal links between alcohol abuse or dependence and major depression database.

Fister, K., \& McKee, M. (2005). Health and health care in transitional Europe. British Medical Journal, 331(7510), 169-170.

Gallet, C. A. (2007). The demand for alcohol: A meta-analysis of elasticities. Australian Journal of Agricultural and Resource Economics, 51(2), 121-135.

Gil, A., Polikina, O., Koroleva, N., Leon, D. A., \& McKee, M. (2010). Alcohol policy in a russian region: A stakeholder analysis. European Journal of Public Health, 20(5), 588-594.

Gilmore, A., Pomerleau, J., McKee, M., Rose, R., Haerpfer, C. W., Rotman, D. et al. (2004). Prevalence of smoking in 8 countries of the former soviet union: Results from the living conditions, lifestyles and health study. American Journal of Public Health, 94(12), 2177-2187.

Gold, J. H. (1998). Gender differences in psychiatric illness and treatments: A critical review. Journal of Nervous and Mental Disease, 186(12), 769-775.

Grant, B. F., \& Hartford, T. C. (1995). Comorbidity between DSM-IV alcohol use disorders and major depression: Results of a national survey. Drug and Alcohol Dependence, 39(3), 197-206.

Grant, V. V., Stewart, S. H., \& Mohr, C. D. (2009). Coping-anxiety and coping-depression motives predict different daily mood-drinking relationships. Psychology of Addictive Behaviors, 23(2), 226-237.

Groot, W. (2000). Adaptation and scale of reference bias in self-assessments of quality of life. Journal of Health Economics, 19(3), 403-420.

Hasin, D. S., \& Grant, B. F. (2002). Major depression in 6050 former drinkers: Association with past alcohol dependence. Archives of General Psychiatry, 59(9), 794-800.

Heyink, J. W. (1993). Adaptation and well-being. Psychological Reports, 73(3), 1331-1342.

Hinote, B. P., Cockerham, W. C., \& Abbott, P. (2009). Psychological distress and dietary patterns in eight post-soviet republics. Appetite, 53(1), 24-33.

Jenkins, R., Klein, J., \& Parker, C. (2005). Mental health in post-communist countries. British Medical Journal, 331(7510), 173-174.

Jenkins, R., McDaid, D., Nikiforov, A., Potasheva, A., Watkins, J., Lancashire, S. et al. (2010). Mental health care reforms in europe: Rehabilitation and social inclusion of people with mental illness in russia. Psychiatric Services, 61(3), 222-224.

Jurges, H. (2007). True health vs response styles: Exploring cross-country differences in self-reported health. Health Economics, 16(2), 163-178.

Kahneman, D., \& Krueger, A. B. (2006). Developments in the measurement of subjective well-being. Journal of Economic Perspectives, 20(1), 3-24.

Kelly, J. F., Stout, R. L., Magill, M., Tonigan, J. S., \& Pagano, M. E. (2010). Mechanisms of behavior change in alcoholics anonymous: Does alcoholics anonymous lead to better alcohol use outcomes by reducing depression symptoms? Addiction, 105(4), 626-636.

Kessler, R. C., Crum, R. M., Warner, L. A., Nelson, C. B., Schulenberg, J., \& Anthony, J. C. (1997). Lifetime co-occurrence of DSM-III-R alcohol abuse and dependence with other psychiatric disorders in the national comorbidity survey. Archives of General Psychiatry, 54(4), 313-321. 
Kim, H. K., \& McKenry, P. C. (2002). The relationship between marriage and psychological well-being. Journal of Family Issues, 23(8), 885-911.

Kitchens, J. M. (1994). Does this patient have an alcohol problem? JAMA: The Journal of the American Medical Association, 272(22), 1782-1787.

Krasovsky, K. (2009). Alcohol-related mortality in ukraine. Drug Alcohol Review, 28(4), 396-405.

Kuo, P. H., Gardner, C. O., Kendler, K. S., \& Prescott, C. A. (2006). The temporal relationship of the onsets of alcohol dependence and major depression: Using a genetically informative study design. Psychological Medicine, 36(8), 1153-1162.

Leon, D. A., Saburova, L., Tomkins, S., McKee, M., \& Shkolnikov, V. M. (2007). Alcohol consumption and public health in russia. The Lancet, 370(9587), 561.

Leon, D. A., \& Shkolnikov, V. M. (1998). Social stress and the russian mortality crisis. Journal of the American Medical Association, 279(10), 790-791.

Lim, S. S., Vos, T., Flaxman, A. D., Danaei, G., Shibuya, K., Adair-Rohani, H. et al. (2012). A comparative risk assessment of burden of disease and injury attributable to 67 risk factors and risk factor clusters in 21 regions, 1990?2010: A systematic analysis for the global burden of disease study 2010. The Lancet, 380(9859), 2224-2260.

Livingston, M. (2011). Alcohol outlet density and harm: Comparing the impacts on violence and chronic harms. Drug and Alcohol Review, 30(5), 515-523.

Livingston, M., Livingston, M., Chikritzhs, T., Livingston, M., Chikritzhs, T., Room, R. et al. (2007). Changing the density of alcohol outlets to reduce alcohol-related problems. Drug Alcohol Rev, 26(5), 557-566.

Lund, C., Breen, A., Flisher, A. J., Kakuma, R., Corrigall, J., Joska, J. A. et al. (2010). Poverty and common mental disorders in low and middle income countries: A systematic review. Social Science \& Medicine, 71(3), 517-528.

Maddala, G. S. (1983). Limited-dependent and qualitative variables in econometrics. Cambridge, UK: Econometric Society Monographs in Quantitative Economics, Cambridge.

McBride, M. (2001). Relative-income effects on subjective well-being in the cross-section. Journal of Economic Behavior \& Organization, 45(3), 251-278.

McDaid, D., Samyshkin, Y. A., Jenkins, R., Potasheva, A., Nikiforov, A., \& Ali Atun, R. (2006). Health system factors impacting on delivery of mental health services in russia: Multi-methods study. Health Policy, 79(2-3), 144-152.

Mentzakis, E., Suhrcke, M., Roberts, B., Murphy, A., \& McKee, M. (2013). Estimating the causal effect of alcohol consumption on well-being for a cross-section of 9 former soviet union countries. Social Science \& Medicine, 89, 1-7.

Mentzakis, E. (2011). Allowing for heterogeneity in monetary subjective well-being valuations. Health Economics, 20(3), 331-347.

Mentzakis, E., McNamee, P., Ryan, M., \& Sutton, M. (2012). Valuing informal care experience: Does choice of measure matter? Social Indicators Research, 108(1), 169-184.

Mentzakis, E., \& Moro, M. (2009). The poor, the rich and the happy: Exploring the link between income and subjective well-being. Journal of Socio-Economics, 38(1), 147-158.

Moskalewicz, J., \& Simpura, J. (2000). The supply of alcoholic beverages in transitional conditions: The case of central and eastern europe. Addiction, 95 Suppl 4, S505-22.

Nelson, J. P. (1999). Broadcast advertising and U.S. demand for alcoholic beverages. Southern Economic Journal, 65(4), 774-790. 
Nemtsov, A. (2011). A contemporary history of alcohol in russia. Stockholm: Södertörns högskola.

Nicholson, A., Bobak, M., Murphy, M., Rose, R., \& Marmot, M. (2005). 2626461; alcohol consumption and increased mortality in russian men and women: A cohort study based on the mortality of relatives. Bulletin of the World Health Organization, 83(11), 812-819.

Ogborne, A. C., \& Smart, R. G. (1980). Will restrictions on alcohol advertising reduce alcohol consumption? British Journal of Addiction, 75(3), 293-296.

Patel, V., Araya, R., de Lima, M., Ludermir, A., \& Todd, C. (1999). Women, poverty and common mental disorders in four restructuring societies. Social Science \& Medicine, 49(11), 1461-1471.

Pietila, I., \& Rytkonen, M. (2008). Coping with stress and by stress: Russian men and women talking about transition, stress and health. Social Science \& Medicine, 66(2), 327-338.

Plavinski, S. L., Plavinskaya, S. I., \& Klimov, A. N. (2003). 161552; social factors and increase in mortality in russia in the 1990s: Prospective cohort study. British Medical Journal, 326(7401), 1240-1242.

Pomerleau, J., McKee, M., Rose, R., Haerpfer, C. W., Rotman, D., \& Tumanov, S. (2005). Drinking in the commonwealth of independent states - evidence from eight countries. Addiction, 100(11), 1647-1668.

Popova, S., Giesbrecht, N., Bekmuradov, D., \& Patra, J. (2009). Hours and days of sale and density of alcohol outlets: Impacts on alcohol consumption and damage: A systematic review. Alcohol and Alcoholism, 44(5), 500-516.

Rechel, B., Kennedy, C., McKee, M., \& Rechel, B. (2011). The soviet legacy in diagnosis and treatment: Implications for population health. Journal of Public Health Policy, 32(3), 293-304.

Rehm, J., Baliunas, D., Borges, G. L., Graham, K., Irving, H., Kehoe, T. et al. (2010). 3306013; the relation between different dimensions of alcohol consumption and burden of disease: An overview. Addiction, 105(5), 817-843.

Roberts, B., Abbott, P., \& McKee, M. (2012). Changes in the levels of psychological distress in eight countries of the former soviet union. Journal of Public Mental Health,

Roberts, B., Abbott, P., \& McKee, M. (2010). Levels and determinants of psychological distress in eight countries of the former soviet union. Journal of Public Mental Health, 9(3), 17-26.

Roberts, B., Stickley, A., Murphy, A., Kizilova, K., Bryden, A., Rotman, D. et al. (2012a). Patterns of public support for price increases on alcohol in the former soviet union. Alcohol and Alcoholism, 47(4), 473-478.

Roberts, B., Gilmore, A., Stickley, A., Rotman, D., Prohoda, V., Haerpfer, C. et al. (2012b). Changes in smoking prevalence in 8 countries of the former soviet union between 2001 and 2010. Am J Public Health, 102(7), 1320-1328.

Roodman, D. (2011). Fitting fully observed recursive mixed-process models with cmp. Stata Journal, 11(2), 159-206.

Sacco, P., Bucholz, K. K., \& Spitznagel, E. L. (2009). 2776115; alcohol use among older adults in the national epidemiologic survey on alcohol and related conditions: A latent class analysis. Journal of Studies on Alcohol and Drugs, 70(6), 829-838.

Saffer, H. (1991). Alcohol advertising bans and alcohol abuse: An international perspective. Journal of Health Economics, 10(1), 65-79.

Saffer, H., \& Dave, D. (2006). Alcohol advertising and alcohol consumption by adolescents. Health Economics, 15(6), 617-637.

Saffer, H., \& Dave, D. (2002). Alcohol consumption and alcohol advertising bans. Applied Economics, $34(11), 1325-1334$. 
Shkolnikov, V., McKee, M., \& Leon, D. A. (2001). Changes in life expectancy in Russia in the mid-1990s. The Lancet, 357(9260), 917-921.

Smith, L., \& Foxcroft, D. (2009). The effect of alcohol advertising, marketing and portrayal on drinking behaviour in young people: Systematic review of prospective cohort studies. BMC Public Health, 9(1), 51.

Snyder, L. B., Milici, F. F., Slater, M., Sun, H., \& Strizhakova, Y. (2006). Effects of alcohol advertising exposure on drinking among youth. Arch Pediatr Adolesc Med, 160(1), 18-24.

Stuckler, D., King, L., \& McKee, M. (2009). Mass privatisation and the post-communist mortality crisis: A cross-national analysis. The Lancet, 373(9661) 399-407.

Terza, J. (1985). Ordinal probit: A generalisation. Communications in Statistics - Theory and Methods, 14, $1-11$.

Tomasson, K., \& Vaglum, P. (1996). Psychopathoiogy and alcohol consumption among treatment-seeking alcoholics: A prospective study. Addiction, 91(7), 1019-1030.

Tomkins, S., Collier, T., Oralov, A., Saburova, L., McKee, M., Shkolnikov, V. et al. (2012). 3275563; hazardous alcohol consumption is a major factor in male premature mortality in a typical Russian city: Prospective cohort study 2003-2009. PLoS One, 7(2), e30274.

Tomov, T., Van Voren, R., Keukens, R., \& Puras, D. (2007). Mental helath policy in former eastern bloc countries. In Knapp M, McDaid D, Mossialos E \& Thornicroft G (Eds.). Maidenhead (UK): Open University Press.

Treisman, D. (2010). Death and prices: The political economy of russia's alcohol crisis. Economics of Transition, 18(2), 281-331.

UNDP. (2011). Beyond transition: Towards inclusive societies. Bratislava: United Nations Development Programme. from the Beyond Transition: Towards Inclusive Societies database.

UNICEF. (2001). A decade of transition. Florence, Italy: UNICEF.

Wang, J., \& Patten, S. B. (2002). Prospective study of frequent heavy alcohol use and the risk of major depression in the canadian general population. Depression and Anxiety, 15(1), 42-45.

Wang, J., \& Patten, S. B. (2001). Alcohol consumption and major depression: Findings from a follow-up study. Canadian Journal of Psychiatry, 46(7), 632-638.

WHO. (2011a). Global status report on alcohol and health. Geneva, Switzerland: World Health Organization.

WHO. (2011b). Global status report on alcohol and health. Geneva: World Health Organization. from the Global status report on alcohol and health database.

WHO. (2000). Women's mental health: An evidence based review. Geneva: World Health Organization. from the Women's mental health: an evidence based review database.

WHO/Europe. (2013). European HFA DatabaseWorld Health Organisation/Europe. http://data.euro.who.int/hfadb/

Williams, R. (2006). Generalized ordered logit/partial proportional odds models for ordinal dependent variables. Stata Journal, 6(1), 58-82.

Zaridze, D., Brennan, P., Boreham, J., Boroda, A., Karpov, R., Lazarev, A. et al. (2009). Alcohol and causespecific mortality in russia: A retrospective case-control study of 48,557 adult deaths. The Lancet, 373(9682), 2201-2214. 
Table 1: Sample statistics for Psychological distress

\begin{tabular}{lcc}
\hline & $\begin{array}{c}\text { Full sample } \\
(\mathrm{N}=16,342)\end{array}$ & $\begin{array}{c}\text { Restricted sample } \\
(\mathrm{N}=2,011)\end{array}$ \\
\cline { 2 - 3 } Not concentrated & 0.235 & 0.236 \\
Insomnia & 0.375 & 0.378 \\
Constant internal strain & 0.310 & 0.305 \\
Not overcoming difficulties & 0.196 & 0.208 \\
Not enjoying daily activities & 0.292 & 0.308 \\
Losing self-confidence & 0.143 & 0.145 \\
Nervous shaking or trembling & 0.200 & 0.191 \\
Frightening thoughts & 0.263 & 0.284 \\
Exhaustion or fatigue & 0.389 & 0.396 \\
Stress & 0.287 & 0.296 \\
Feeling lonely & 0.235 & 0.234 \\
Dissatisfied with work & 0.263 & 0.277 \\
Not able to influence things & 0.253 & 0.271 \\
Life is too complicated & 0.384 & 0.407 \\
\hline Overall Psychological distress score (Min = ; Max $=14)$ & 3.270 & 3.351 \\
Collapsed overall Psychological distress score (Min =0; Max $=6)$ & 2.786 & 2.834 \\
\hline
\end{tabular}

Mean values are not significantly different between the two samples for any variable

Table 2: Prevalence of problem drinking (i.e. $C A G E \geq 2$ ) by country

\begin{tabular}{lcc}
\hline & Full sample $(\mathrm{N}=16,342)$ & Restricted sample $(\mathrm{N}=2,011)$ \\
\cline { 2 - 3 } Armenia & $9.86(\mathrm{~N}=1644)$ & $14.21(\mathrm{~N}=183)$ \\
Berbaijan & $5.72(\mathrm{~N}=1661)$ & $11.36(\mathrm{~N}=44)$ \\
Georgia & $18.25(\mathrm{~N}=1644)$ & $19.28(\mathrm{~N}=83)$ \\
Kazakhstan & $10.76(\mathrm{~N}=2064)$ & $11.3(\mathrm{~N}=300)$ \\
Kyrgyzstan & $13.42(\mathrm{~N}=1692)$ & $16.94(\mathrm{~N}=248)$ \\
Moldova & $11.02(\mathrm{~N}=1742)$ & $10.84(\mathrm{~N}=249)$ \\
Russia & $16.15(\mathrm{~N}=1622)$ & $13.18(\mathrm{~N}=220)$ \\
Ukraine & $16.04(\mathrm{~N}=2543)$ & $15.81(\mathrm{~N}=506)$ \\
\hline Total & $15.32(\mathrm{~N}=1710)$ & $19.10(\mathrm{~N}=178)$ \\
\hline \multicolumn{2}{l}{ Mean values are not significantly different between the two samples for any country } \\
\multicolumn{2}{l}{14.57}
\end{tabular}


Table 3: Sample descriptive statistics for demographic and socio-economic variables

\begin{tabular}{|c|c|c|c|c|c|c|}
\hline \multirow[b]{3}{*}{ Male } & \multicolumn{3}{|c|}{$\begin{array}{l}\text { Full sample } \\
(\mathrm{N}=16,342)\end{array}$} & \multicolumn{3}{|c|}{$\begin{array}{l}\text { Restricted sample } \\
(\mathrm{N}=2,011)\end{array}$} \\
\hline & Mean & Min & $\operatorname{Max}$ & Mean & Min & $\operatorname{Max}$ \\
\hline & 0.438 & & & 0.447 & & \\
\hline Age & 42.46 & 18 & 95 & 43.12 & 18 & 90 \\
\hline Married & 0.624 & & & 0.610 & & \\
\hline Single & 0.208 & & & 0.204 & & \\
\hline Higher education $^{a}$ & 0.276 & & & 0.309 & & \\
\hline $\mathrm{HH}$ size $^{\mathrm{a}}$ & 3.669 & 1 & 15 & 3.552 & 1 & 15 \\
\hline \# of children & 0.780 & 0 & 10 & 0.755 & 0 & 10 \\
\hline Employed & 0.464 & & & 0.466 & & \\
\hline Unemployed & 0.203 & & & 0.186 & & \\
\hline Wealth Index ${ }^{a}$ & 4.235 & 0 & 10 & 4.316 & 0 & 9 \\
\hline (Very) Good financial situation & 0.226 & & & 0.228 & & \\
\hline V. Good/Good Health & 0.418 & & & 0.398 & & \\
\hline (Fairly) easy to walk $1 \mathrm{~km}$ & 0.750 & & & 0.760 & & \\
\hline (Fairly) easy to climb stairs & 0.662 & & & 0.683 & & \\
\hline
\end{tabular}

${ }^{a}$ Mean values are significantly different $5 \%$ level between two samples

Table 4. Descriptive statistics for community level number of alcohol advertisements by country

\begin{tabular}{|c|c|c|c|c|}
\hline \multirow[b]{3}{*}{ Armenia } & \multicolumn{2}{|c|}{ Full sample $(\mathrm{N}=2,385)^{\mathrm{a}}$} & \multicolumn{2}{|c|}{ Restricted sample $(\mathrm{N}=2,011)^{\mathrm{a}}$} \\
\hline & Mean & Std. Dev. & Mean & Std. Dev \\
\hline & $5.00(\mathrm{~N}=205)$ & 3.78 & $5.25(\mathrm{~N}=183)$ & 3.84 \\
\hline Azerbaijan ${ }^{b}$ & $3.11(\mathrm{~N}=112)$ & 3.82 & $1.80(\mathrm{~N}=44)$ & 0.90 \\
\hline Belarus & $2.59(\mathrm{~N}=93)$ & 1.52 & $2.57(\mathrm{~N}=83)$ & 1.50 \\
\hline Georgia & $4.46(\mathrm{~N}=327)$ & 5.22 & $4.12(\mathrm{~N}=300)$ & 4.92 \\
\hline Kazakhstan & $5.57(\mathrm{~N}=300)$ & 10.35 & $5.73(\mathrm{~N}=248)$ & 10.33 \\
\hline Kyrgyzstan & $3.15(\mathrm{~N}=260)$ & 4.84 & $3.00(\mathrm{~N}=249)$ & 4.66 \\
\hline Moldova & $17.15(\mathrm{~N}=247)$ & 12.36 & $17.17(\mathrm{~N}=220)$ & 12.46 \\
\hline Russia & $6.29(\mathrm{~N}=625)$ & 6.61 & $6.31(\mathrm{~N}=506)$ & 6.47 \\
\hline Ukraine & $11.68(\mathrm{~N}=216)$ & 10.68 & $10.97(\mathrm{~N}=178)$ & 10.19 \\
\hline Total & 6.82 & 8.75 & 6.75 & 8.68 \\
\hline
\end{tabular}

Table 5. Descriptive statistics for community level number of alcohol shops by country

\begin{tabular}{|c|c|c|c|c|}
\hline \multirow[b]{3}{*}{ Armenia $^{b}$} & \multicolumn{2}{|c|}{ Full sample $(\mathrm{N}=3,015)^{\mathrm{a}}$} & \multicolumn{2}{|c|}{ Restricted sample $(\mathrm{N}=2,011)^{\mathrm{a}}$} \\
\hline & Mean & Std. Dev. & Mean & Std. Dev. \\
\hline & $6.69(\mathrm{~N}=286)$ & 6.55 & $8.72(\mathrm{~N}=183)$ & 6.98 \\
\hline Azerbaijan & $6.67(\mathrm{~N}=340)$ & 4.74 & $5.82(\mathrm{~N}=44)$ & 3.47 \\
\hline Belarus & $6.91(\mathrm{~N}=263)$ & 6.76 & $8.30(\mathrm{~N}=83)$ & 6.01 \\
\hline Georgia & $6.93(\mathrm{~N}=389)$ & 5.10 & $6.85(\mathrm{~N}=300)$ & 4.39 \\
\hline Kazakhstan & $6.37(\mathrm{~N}=300)$ & 4.58 & $5.94(\mathrm{~N}=248)$ & 3.75 \\
\hline Kyrgyzstan & $5.30(\mathrm{~N}=300)$ & 4.23 & $5.56(\mathrm{~N}=249)$ & 4.40 \\
\hline Moldova & $8.53(\mathrm{~N}=247)$ & 5.15 & $8.59(\mathrm{~N}=220)$ & 5.20 \\
\hline Russia & $6.59(\mathrm{~N}=664)$ & 4.66 & $7.00(\mathrm{~N}=506)$ & 4.72 \\
\hline Ukraine & $6.72(\mathrm{~N}=226)$ & 5.10 & $6.38(\mathrm{~N}=178)$ & 4.83 \\
\hline Total & 6.69 & 5.21 & 6.97 & 4.98 \\
\hline
\end{tabular}

${ }^{a}$ Local community levels values are observed only for a sub-sample of individuals (i.e. N).

${ }^{\mathrm{b}}$ Mean values are significantly different $5 \%$ level between two samples 
Table 6: OLS and IV estimation results of the effect of problem drinking on number of mental distress problems reported using the square of alcohol advertisement as instrument

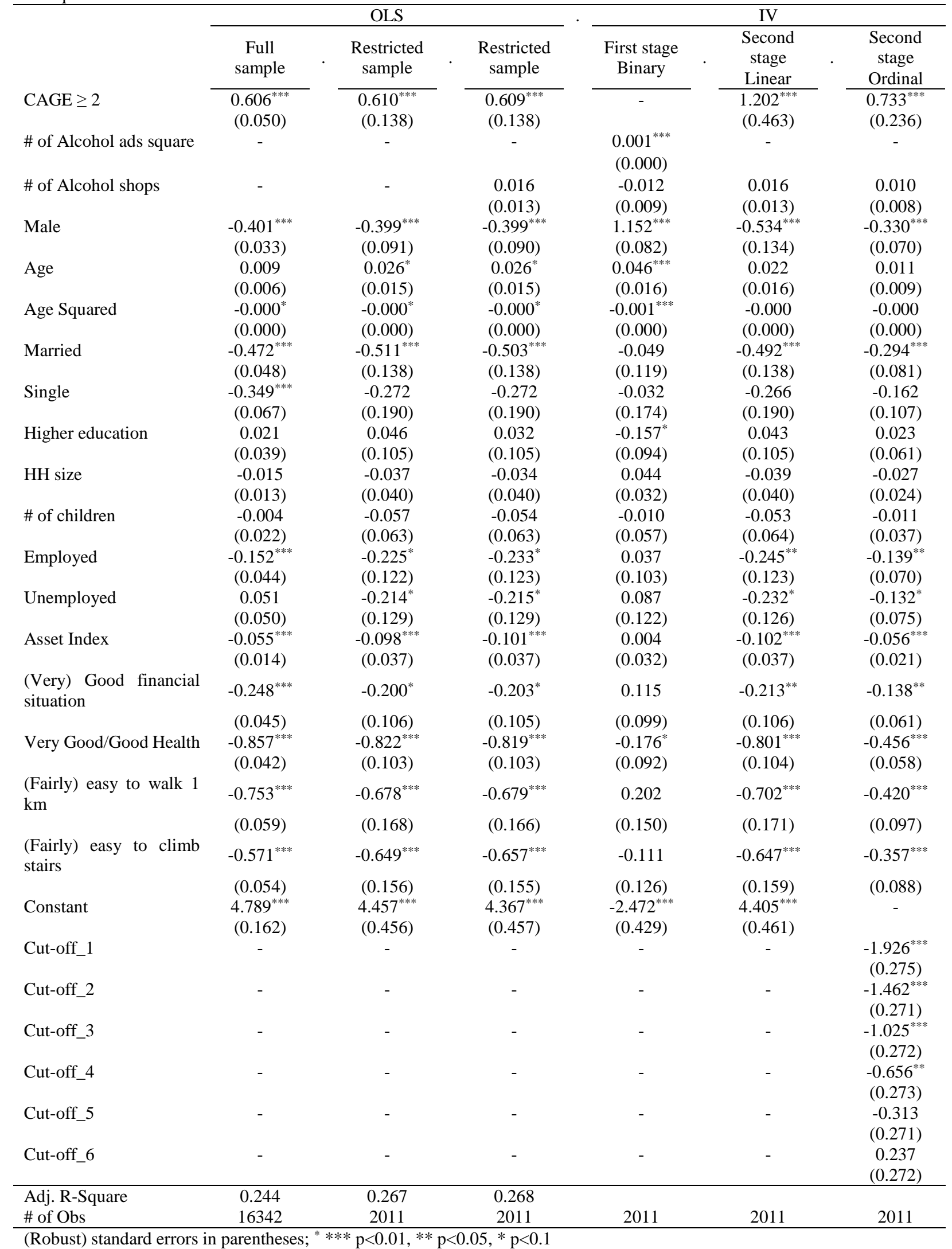


Table 7: Marginal effects for the IV ordinal model using the square of alcohol advertisement as instrument

\begin{tabular}{|c|c|c|c|c|c|c|c|}
\hline & $\begin{array}{c}(1) \\
\text { Mental } \\
\text { Health }=0\end{array}$ & $\begin{array}{c}(2) \\
\text { Mental } \\
\text { Health =1 }\end{array}$ & $\begin{array}{c}(3) \\
\text { Mental } \\
\text { Health =2 }\end{array}$ & $\begin{array}{c}\text { (4) } \\
\text { Mental } \\
\text { Health =3 }\end{array}$ & $\begin{array}{c}\text { (5) } \\
\text { Mental } \\
\text { Health =4 }\end{array}$ & $\begin{array}{c}(6) \\
\text { Mental } \\
\text { Health =5 }\end{array}$ & $\begin{array}{c}\text { (7) } \\
\text { Mental } \\
\text { Health }=6\end{array}$ \\
\hline $\mathrm{CAGE} \geq 2$ & $\begin{array}{c}-0.178 * * * \\
(0.0576)\end{array}$ & $\begin{array}{c}-0.0449 * * * \\
(0.0125)\end{array}$ & $\begin{array}{c}-0.0176 * * * \\
(0.00585)\end{array}$ & $\begin{array}{c}0.00833^{* * *} * \\
(0.00302)\end{array}$ & $\begin{array}{c}0.0246 * * * \\
(0.00728)\end{array}$ & $\begin{array}{c}0.0593 * * * \\
(0.0174)\end{array}$ & $\begin{array}{c}0.148 * * * \\
(0.0491)\end{array}$ \\
\hline $\begin{array}{l}\# \text { of Alcohol ads } \\
\text { square }\end{array}$ & -0.00236 & -0.000598 & -0.000234 & 0.000111 & 0.000327 & 0.000789 & 0.00197 \\
\hline & $(0.00184)$ & $(0.000467)$ & (0.000186) & $(9.23 \mathrm{e}-05)$ & $(0.000255)$ & $(0.000616)$ & $(0.00153)$ \\
\hline Male & $\begin{array}{c}0.0801 * * * \\
(0.0172)\end{array}$ & $\begin{array}{c}0.0202 * * * \\
(0.00391)\end{array}$ & $\begin{array}{c}0.00793 * * * \\
(0.00196)\end{array}$ & $\begin{array}{c}-0.00375 * * * \\
(0.00122)\end{array}$ & $\begin{array}{c}-0.0111 * * * \\
(0.00230)\end{array}$ & $\begin{array}{c}-0.0267 * * * \\
(0.00523)\end{array}$ & $\begin{array}{c}-0.0667 * * * \\
(0.0148)\end{array}$ \\
\hline Age & $\begin{array}{l}-0.000387 \\
(0.000636)\end{array}$ & $\begin{array}{c}2.67 \mathrm{e}-05 \\
(0.000131)\end{array}$ & $\begin{array}{c}0.000118 \\
(0.000108)\end{array}$ & $\begin{array}{c}0.000140 \\
(0.000122)\end{array}$ & $\begin{array}{c}0.000126 \\
(0.000131)\end{array}$ & $\begin{array}{c}0.000126 \\
(0.000209)\end{array}$ & $\begin{array}{l}-0.000150 \\
(0.000437)\end{array}$ \\
\hline Married & $\begin{array}{c}0.0711 * * * \\
(0.0194)\end{array}$ & $\begin{array}{c}0.0180 * * * \\
(0.00551)\end{array}$ & $\begin{array}{c}0.00705^{* * *} \\
(0.00230)\end{array}$ & $\begin{array}{c}-0.00334 * * \\
(0.00144)\end{array}$ & $\begin{array}{c}-0.00984 * * * \\
(0.00301)\end{array}$ & $\begin{array}{c}-0.0238 * * * \\
(0.00688)\end{array}$ & $\begin{array}{c}-0.0593 * * * \\
(0.0163)\end{array}$ \\
\hline Single & $\begin{array}{c}0.0392 \\
(0.0258)\end{array}$ & $\begin{array}{c}0.00990 \\
(0.00673)\end{array}$ & $\begin{array}{c}0.00388 \\
(0.00263)\end{array}$ & $\begin{array}{l}-0.00184 \\
(0.00137)\end{array}$ & $\begin{array}{l}-0.00542 \\
(0.00366)\end{array}$ & $\begin{array}{c}-0.0131 \\
(0.00867)\end{array}$ & $\begin{array}{l}-0.0326 \\
(0.0216)\end{array}$ \\
\hline Higher education & $\begin{array}{l}-0.00569 \\
(0.0147)\end{array}$ & $\begin{array}{l}-0.00144 \\
(0.00371)\end{array}$ & $\begin{array}{l}-0.000563 \\
(0.00146)\end{array}$ & $\begin{array}{c}0.000267 \\
(0.000689)\end{array}$ & $\begin{array}{l}0.000786 \\
(0.00202)\end{array}$ & $\begin{array}{c}0.00190 \\
(0.00489)\end{array}$ & $\begin{array}{l}0.00474 \\
(0.0123)\end{array}$ \\
\hline HH size & $\begin{array}{c}0.00662 \\
(0.00590)\end{array}$ & $\begin{array}{c}0.00167 \\
(0.00146)\end{array}$ & $\begin{array}{c}0.000656 \\
(0.000574)\end{array}$ & $\begin{array}{l}-0.000310 \\
(0.000294)\end{array}$ & $\begin{array}{c}-0.000915 \\
(0.000825)\end{array}$ & $\begin{array}{l}-0.00221 \\
(0.00196)\end{array}$ & $\begin{array}{l}-0.00551 \\
(0.00487)\end{array}$ \\
\hline \# of children & $\begin{array}{c}0.00265 \\
(0.00889)\end{array}$ & $\begin{array}{l}0.000670 \\
(0.00226)\end{array}$ & $\begin{array}{c}0.000262 \\
(0.000889)\end{array}$ & $\begin{array}{l}-0.000124 \\
(0.000418)\end{array}$ & $\begin{array}{l}-0.000366 \\
(0.00123)\end{array}$ & $\begin{array}{l}-0.000885 \\
(0.00297)\end{array}$ & $\begin{array}{l}-0.00221 \\
(0.00742)\end{array}$ \\
\hline Employed & $\begin{array}{c}0.0336 * * \\
(0.0168)\end{array}$ & $\begin{array}{l}0.00849^{*} \\
(0.00433)\end{array}$ & $\begin{array}{l}0.00333^{*} \\
(0.00178)\end{array}$ & $\begin{array}{l}-0.00157^{*} \\
(0.000939)\end{array}$ & $\begin{array}{l}-0.00464 * \\
(0.00238)\end{array}$ & $\begin{array}{l}-0.0112 * * \\
(0.00567)\end{array}$ & $\begin{array}{c}-0.0280^{* *} \\
(0.0140)\end{array}$ \\
\hline Unemployed & $\begin{array}{l}0.0320 * \\
(0.0181)\end{array}$ & $\begin{array}{l}0.00809^{*} \\
(0.00460)\end{array}$ & $\begin{array}{l}0.00317 * \\
(0.00186)\end{array}$ & $\begin{array}{c}-0.00150 \\
(0.000982)\end{array}$ & $\begin{array}{l}-0.00443 * \\
(0.00253)\end{array}$ & $\begin{array}{l}-0.0107 * \\
(0.00600)\end{array}$ & $\begin{array}{l}-0.0267 * \\
(0.0151)\end{array}$ \\
\hline Asset Index & $\begin{array}{c}0.0136 * * * \\
(0.00509)\end{array}$ & $\begin{array}{c}0.00344 * * * \\
(0.00132)\end{array}$ & $\begin{array}{l}0.00135^{* *} \\
(0.000545)\end{array}$ & $\begin{array}{c}-0.000639 * * \\
(0.000300)\end{array}$ & $\begin{array}{c}-0.00188 * * * \\
(0.000725)\end{array}$ & $\begin{array}{c}-0.00455 * * * \\
(0.00173)\end{array}$ & $\begin{array}{c}-0.0113 * * * \\
(0.00425)\end{array}$ \\
\hline $\begin{array}{l}\text { (Very) Good } \\
\text { financial situation }\end{array}$ & $0.0335^{* *}$ & $0.00848 * *$ & $0.00332 * *$ & $-0.00157 *$ & $-0.00464 * *$ & $-0.0112 * *$ & $-0.0279 * *$ \\
\hline & $(0.0147)$ & $(0.00374)$ & $(0.00151)$ & $(0.000807)$ & $(0.00203)$ & $(0.00487)$ & $(0.0124)$ \\
\hline $\begin{array}{l}\text { Very } \quad \text { Good/Good } \\
\text { Health }\end{array}$ & $0.111 * * *$ & $0.0279 * * *$ & $0.0109 * * *$ & $-0.00518 * * *$ & $-0.0153 * * *$ & $-0.0369 * * *$ & $-0.0920 * * *$ \\
\hline & $(0.0140)$ & $(0.00444)$ & $(0.00230)$ & $(0.00170)$ & $(0.00252)$ & $(0.00516)$ & $(0.0122)$ \\
\hline $\begin{array}{l}\text { (Fairly) easy to walk } \\
\text { a } 1 \mathrm{~K}\end{array}$ & $0.102 * * *$ & $0.0257 * * *$ & $0.0101 * * *$ & $-0.00477 * * *$ & $-0.0141 * * *$ & $-0.0340 * * *$ & $-0.0847 * * *$ \\
\hline & $(0.0240)$ & $(0.00596)$ & $(0.00259)$ & $(0.00183)$ & $(0.00342)$ & $(0.00795)$ & (0.0198) \\
\hline $\begin{array}{l}\text { (Fairly) easy to climb } \\
\text { stairs }\end{array}$ & $0.0865^{* * *}$ & $0.0219 * * *$ & $0.00856^{* * *}$ & $-0.00405 * * *$ & $-0.0120 * * *$ & $-0.0289 * * *$ & $-0.0720 * * *$ \\
\hline & $(0.0209)$ & $(0.00593)$ & $(0.00256)$ & $(0.00154)$ & $(0.00329)$ & $(0.00733)$ & $(0.0177)$ \\
\hline bservations & & & & 2,011 & & & \\
\hline
\end{tabular}


Table 8: : OLS and IV estimation results of the effect of problem drinking on number of mental distress problems reported using the level of alcohol advertisement as instrument

\begin{tabular}{|c|c|c|c|c|c|c|}
\hline \multirow[b]{3}{*}{$\mathrm{CAGE} \geq 2$} & \multicolumn{3}{|c|}{ OLS } & \multicolumn{3}{|c|}{ IV } \\
\hline & $\begin{array}{c}\text { Full } \\
\text { sample }\end{array}$ & $\begin{array}{l}\text { Restricted } \\
\text { sample }\end{array}$ & $\begin{array}{l}\text { Restricted } \\
\text { sample }\end{array}$ & $\begin{array}{c}\text { First stage } \\
\text { Binary }\end{array}$ & $\begin{array}{l}\text { Second } \\
\text { stage } \\
\text { Linear }\end{array}$ & $\begin{array}{l}\text { Second } \\
\text { stage } \\
\text { Ordinal }\end{array}$ \\
\hline & $\begin{array}{c}0.606^{* * * *} \\
(0.050)\end{array}$ & $\begin{array}{c}0.610^{* * * *} \\
(0.138)\end{array}$ & $\begin{array}{c}0.609^{* * * *} \\
(0.138)\end{array}$ & - & $\begin{array}{c}1.531^{* * * *} \\
(0.503)\end{array}$ & $\begin{array}{c}0.896^{* * *} \\
(0.231)\end{array}$ \\
\hline \# of Alcohol ads & - & - & - & $\begin{array}{c}0.024^{* * *} \\
(0.009)\end{array}$ & - & - \\
\hline \# of Alcohol shops & - & - & $\begin{array}{c}0.016 \\
(0.013)\end{array}$ & $\begin{array}{c}-0.013 \\
(0.010)\end{array}$ & $\begin{array}{c}0.016 \\
(0.013)\end{array}$ & $\begin{array}{c}0.010 \\
(0.008)\end{array}$ \\
\hline Male & $\begin{array}{c}-0.401^{* * * *} \\
(0.033)\end{array}$ & $\begin{array}{c}-0.399^{* * * *} \\
(0.091)\end{array}$ & $\begin{array}{c}-0.399^{* * * *} \\
(0.090)\end{array}$ & $\begin{array}{l}1.144^{* * * *} \\
(0.081)\end{array}$ & $\begin{array}{c}-0.608^{* * * *} \\
(0.143)\end{array}$ & $\begin{array}{c}-0.366^{* * * *} \\
(0.070)\end{array}$ \\
\hline Age & $\begin{array}{c}0.009 \\
(0.006)\end{array}$ & $\begin{array}{l}0.026^{*} \\
(0.015)\end{array}$ & $\begin{array}{c}0.026^{*} \\
(0.015)\end{array}$ & $\begin{array}{c}0.044^{* * * *} \\
(0.016)\end{array}$ & $\begin{array}{c}0.020 \\
(0.016)\end{array}$ & $\begin{array}{c}0.009 \\
(0.009)\end{array}$ \\
\hline Age Squared & $\begin{array}{l}-0.000^{*} \\
(0.000)\end{array}$ & $\begin{array}{l}-0.000^{*} \\
(0.000)\end{array}$ & $\begin{array}{l}-0.000^{*} \\
(0.000)\end{array}$ & $\begin{array}{c}-0.001^{* * * *} \\
(0.000)\end{array}$ & $\begin{array}{l}-0.000 \\
(0.000)\end{array}$ & $\begin{array}{c}-0.000 \\
(0.000)\end{array}$ \\
\hline Married & $\begin{array}{c}-0.472^{* * * *} \\
(0.048)\end{array}$ & $\begin{array}{c}-0.511^{* * * *} \\
(0.138)\end{array}$ & $\begin{array}{c}-0.503^{* * * *} \\
(0.138)\end{array}$ & $\begin{array}{l}-0.045 \\
(0.120)\end{array}$ & $\begin{array}{c}-0.486^{* * * *} \\
(0.140)\end{array}$ & $\begin{array}{c}-0.288^{* * * *} \\
(0.082)\end{array}$ \\
\hline Single & $\begin{array}{c}-0.349^{* * * *} \\
(0.067)\end{array}$ & $\begin{array}{l}-0.272 \\
(0.190)\end{array}$ & $\begin{array}{l}-0.272 \\
(0.190)\end{array}$ & $\begin{array}{c}-0.024 \\
(0.175)\end{array}$ & $\begin{array}{l}-0.263 \\
(0.191)\end{array}$ & $\begin{array}{l}-0.159 \\
(0.107)\end{array}$ \\
\hline Higher education & $\begin{array}{c}0.021 \\
(0.039)\end{array}$ & $\begin{array}{c}0.046 \\
(0.105)\end{array}$ & $\begin{array}{c}0.032 \\
(0.105)\end{array}$ & $\begin{array}{l}-0.153^{*} \\
(0.093)\end{array}$ & $\begin{array}{c}0.050 \\
(0.106)\end{array}$ & $\begin{array}{c}0.026 \\
(0.060)\end{array}$ \\
\hline $\mathrm{HH}$ size & $\begin{array}{c}-0.015 \\
(0.013)\end{array}$ & $\begin{array}{l}-0.037 \\
(0.040)\end{array}$ & $\begin{array}{l}-0.034 \\
(0.040)\end{array}$ & $\begin{array}{c}0.047 \\
(0.032)\end{array}$ & $\begin{array}{l}-0.042 \\
(0.041)\end{array}$ & $\begin{array}{l}-0.029 \\
(0.024)\end{array}$ \\
\hline \# of children & $\begin{array}{c}-0.004 \\
(0.022)\end{array}$ & $\begin{array}{c}-0.057 \\
(0.063)\end{array}$ & $\begin{array}{c}-0.054 \\
(0.063)\end{array}$ & $\begin{array}{c}-0.014 \\
(0.057)\end{array}$ & $\begin{array}{l}-0.052 \\
(0.064)\end{array}$ & $\begin{array}{c}-0.010 \\
(0.037)\end{array}$ \\
\hline Employed & $\begin{array}{c}-0.152^{* * * *} \\
(0.044)\end{array}$ & $\begin{array}{l}-0.225^{*} \\
(0.122)\end{array}$ & $\begin{array}{l}-0.233^{*} \\
(0.123)\end{array}$ & $\begin{array}{c}0.042 \\
(0.103)\end{array}$ & $\begin{array}{c}-0.252^{* *} \\
(0.124)\end{array}$ & $\begin{array}{c}-0.141^{* *} \\
(0.069)\end{array}$ \\
\hline Unemployed & $\begin{array}{c}0.051 \\
(0.050)\end{array}$ & $\begin{array}{l}-0.214^{*} \\
(0.129)\end{array}$ & $\begin{array}{l}-0.215^{*} \\
(0.129)\end{array}$ & $\begin{array}{c}0.090 \\
(0.122)\end{array}$ & $\begin{array}{l}-0.241^{*} \\
(0.126)\end{array}$ & $\begin{array}{l}-0.136^{*} \\
(0.074)\end{array}$ \\
\hline Asset Index & $\begin{array}{c}-0.055^{\text {**** }} \\
(0.014)\end{array}$ & $\begin{array}{c}-0.098^{* * * *} \\
(0.037)\end{array}$ & $\begin{array}{c}-0.101^{* * * *} \\
(0.037)\end{array}$ & $\begin{array}{c}0.001 \\
(0.033)\end{array}$ & $\begin{array}{c}-0.102^{* * * *} \\
(0.037)\end{array}$ & $\begin{array}{c}-0.056^{* * * *} \\
(0.021)\end{array}$ \\
\hline $\begin{array}{l}\text { (Very) Good } \\
\text { financial situation }\end{array}$ & $-0.248^{* * *}$ & $-0.200^{*}$ & $-0.203^{*}$ & 0.115 & $-0.219^{* *}$ & $-0.140^{* *}$ \\
\hline & $(0.045)$ & $(0.106)$ & $(0.105)$ & $(0.099)$ & $(0.107)$ & $(0.060)$ \\
\hline $\begin{array}{l}\text { Very Good/Good } \\
\text { Health }\end{array}$ & $-0.857^{* * * *}$ & $-0.822^{* * *}$ & $-0.819^{* * *}$ & $-0.173^{*}$ & $-0.791^{* * * *}$ & $-0.447^{* * *}$ \\
\hline & $(0.042)$ & $(0.103)$ & $(0.103)$ & $(0.093)$ & $(0.106)$ & $(0.059)$ \\
\hline $\begin{array}{l}\text { (Fairly) easy to } \\
\text { walk a } 1 \mathrm{~K}\end{array}$ & $-0.753^{* * *}$ & $-0.678^{* * * *}$ & $-0.679^{* * *}$ & 0.209 & $-0.715^{* * *}$ & $-0.423^{* * *}$ \\
\hline & $(0.059)$ & $(0.168)$ & $(0.166)$ & $(0.149)$ & $(0.175)$ & $(0.098)$ \\
\hline $\begin{array}{l}\text { (Fairly) easy to } \\
\text { climb stairs }\end{array}$ & $-0.571^{* * *}$ & $-0.649^{* * *}$ & $-0.657^{* * *}$ & -0.118 & $-0.641^{* * *}$ & $-0.351^{* * * *}$ \\
\hline & $(0.054)$ & $(0.156)$ & $(0.155)$ & $(0.125)$ & $(0.161)$ & $(0.089)$ \\
\hline Constant & $\begin{array}{l}4.789^{* * * *} \\
(0.162)\end{array}$ & $\begin{array}{c}4.457^{* * *} \\
(0.456)\end{array}$ & $\begin{array}{c}4.367^{* * *} \\
(0.457)\end{array}$ & $\begin{array}{c}-2.531^{* * *} \\
(0.433)\end{array}$ & $\begin{array}{c}4.427^{* * *} \\
(0.466)\end{array}$ & - \\
\hline Cut-off_1 & & & & & $(0.126)$ & $(0.125)$ \\
\hline Cut-off_2 & - & - & - & - & - & $\begin{array}{l}-1.922^{* * * *} \\
(0.275)\end{array}$ \\
\hline Cut-off_3 & - & - & - & - & - & $\begin{array}{c}-1.462^{* * * *} \\
(0.271)\end{array}$ \\
\hline Cut-off_4 & - & - & - & - & - & $\begin{array}{c}-1.029^{* * * *} \\
(0.272)\end{array}$ \\
\hline Cut-off_5 & - & - & - & - & - & $\begin{array}{c}-0.663^{* *} \\
(0.273)\end{array}$ \\
\hline Cut-off_6 & - & - & - & - & - & $\begin{array}{l}-0.324 \\
(0.271)\end{array}$ \\
\hline & - & - & - & - & - & 0.222 \\
\hline $\begin{array}{l}\text { Adj. R-Square } \\
\# \text { of Obs }\end{array}$ & $\begin{array}{l}0.244 \\
16342 \\
\end{array}$ & $\begin{array}{l}0.267 \\
2011 \\
\end{array}$ & $\begin{array}{l}0.268 \\
2011 \\
\end{array}$ & 2011 & 2011 & 2011 \\
\hline
\end{tabular}


(Robust) standard errors in parentheses; ${ }^{*} * * * \mathrm{p}<0.01,{ }^{*} * \mathrm{p}<0.05,{ }^{*} \mathrm{p}<0.1$

Table 9: Marginal effects for the IV ordinal model using the level of alcohol advertisement as instrument

\begin{tabular}{|c|c|c|c|c|c|c|c|}
\hline & $\begin{array}{c}(1) \\
\text { Mental } \\
\text { Health }=0\end{array}$ & $\begin{array}{c}(2) \\
\text { Mental } \\
\text { Health }=1\end{array}$ & $\begin{array}{c}(3) \\
\text { Mental } \\
\text { Health =2 }\end{array}$ & $\begin{array}{c}(4) \\
\text { Mental } \\
\text { Health =3 }\end{array}$ & $\begin{array}{c}(5) \\
\text { Mental } \\
\text { Health =4 }\end{array}$ & $\begin{array}{c}(6) \\
\text { Mental } \\
\text { Health =5 }\end{array}$ & $\begin{array}{c}(7) \\
\text { Mental } \\
\text { Health =6 }\end{array}$ \\
\hline $\mathrm{CAGE} \geq 2$ & $\begin{array}{c}-0.218 * * * \\
(0.0571)\end{array}$ & $\begin{array}{c}-0.0528 * * * \\
(0.0109)\end{array}$ & $\begin{array}{c}-0.0207 * * * \\
(0.00546)\end{array}$ & $\begin{array}{c}0.00966^{* * * *} \\
(0.00314)\end{array}$ & $\begin{array}{c}0.0288 * * * \\
(0.00655)\end{array}$ & $\begin{array}{c}0.0703 * * * \\
(0.0160)\end{array}$ & $\begin{array}{c}0.182 * * * \\
(0.0491)\end{array}$ \\
\hline $\begin{array}{l}\# \text { of Alcohol } \\
\text { shops }\end{array}$ & -0.00234 & -0.000567 & -0.000222 & 0.000104 & 0.000309 & 0.000755 & 0.00196 \\
\hline & $(0.00183)$ & $(0.000447)$ & $(0.000179)$ & $(8.72 \mathrm{e}-05)$ & $(0.000244)$ & (0.000594) & $(0.00153)$ \\
\hline Male & $\begin{array}{c}0.0889 * * * \\
(0.0172)\end{array}$ & $\begin{array}{c}0.0216 * * * \\
(0.00365)\end{array}$ & $\begin{array}{c}0.00845^{* * *} \\
(0.00189)\end{array}$ & $\begin{array}{c}-0.00394 * * * \\
(0.00125)\end{array}$ & $\begin{array}{c}-0.0118 * * * \\
(0.00216)\end{array}$ & $\begin{array}{c}-0.0287 * * * \\
(0.00496)\end{array}$ & $\begin{array}{c}-0.0744 * * * \\
(0.0149)\end{array}$ \\
\hline Age & $\begin{array}{c}-0.000332 \\
(0.000638)\end{array}$ & $\begin{array}{c}2.67 \mathrm{e}-05 \\
(0.000126)\end{array}$ & $\begin{array}{c}0.000102 \\
(0.000105)\end{array}$ & $\begin{array}{c}0.000119 \\
(0.000117)\end{array}$ & $\begin{array}{c}0.000106 \\
(0.000127)\end{array}$ & $\begin{array}{c}0.000107 \\
(0.000205)\end{array}$ & $\begin{array}{l}-0.000129 \\
(0.000440)\end{array}$ \\
\hline Married & $\begin{array}{c}0.0700 * * * \\
(0.0196)\end{array}$ & $\begin{array}{c}0.0170 * * * \\
(0.00539)\end{array}$ & $\begin{array}{c}0.00666^{* * *} \\
(0.00223)\end{array}$ & $\begin{array}{c}-0.00311 * * \\
(0.00137)\end{array}$ & $\begin{array}{c}-0.00927 * * * \\
(0.00294)\end{array}$ & $\begin{array}{c}-0.0226 * * * \\
(0.00673)\end{array}$ & $\begin{array}{c}-0.0587 * * * \\
(0.0164)\end{array}$ \\
\hline Single & $\begin{array}{c}0.0386 \\
(0.0259)\end{array}$ & $\begin{array}{c}0.00936 \\
(0.00648)\end{array}$ & $\begin{array}{c}0.00367 \\
(0.00253)\end{array}$ & $\begin{array}{l}-0.00171 \\
(0.00130)\end{array}$ & $\begin{array}{l}-0.00510 \\
(0.00352)\end{array}$ & $\begin{array}{c}-0.0125 \\
(0.00841)\end{array}$ & $\begin{array}{l}-0.0323 \\
(0.0217)\end{array}$ \\
\hline Higher education & $\begin{array}{r}-0.00639 \\
(0.0147)\end{array}$ & $\begin{array}{l}-0.00155 \\
(0.00356)\end{array}$ & $\begin{array}{l}-0.000608 \\
(0.00140)\end{array}$ & $\begin{array}{c}0.000284 \\
(0.000652)\end{array}$ & $\begin{array}{l}0.000846 \\
(0.00193)\end{array}$ & $\begin{array}{c}0.00207 \\
(0.00473)\end{array}$ & $\begin{array}{l}0.00536 \\
(0.0123)\end{array}$ \\
\hline HH size & $\begin{array}{c}0.00693 \\
(0.00589)\end{array}$ & $\begin{array}{c}0.00168 \\
(0.00141)\end{array}$ & $\begin{array}{c}0.000659 \\
(0.000552)\end{array}$ & $\begin{array}{l}-0.000308 \\
(0.000280)\end{array}$ & $\begin{array}{l}-0.000917 \\
(0.000791)\end{array}$ & $\begin{array}{l}-0.00224 \\
(0.00190)\end{array}$ & $\begin{array}{l}-0.00580 \\
(0.00489)\end{array}$ \\
\hline \# of children & $\begin{array}{c}0.00252 \\
(0.00894)\end{array}$ & $\begin{array}{l}0.000612 \\
(0.00218)\end{array}$ & $\begin{array}{c}0.000240 \\
(0.000857)\end{array}$ & $\begin{array}{l}-0.000112 \\
(0.000398)\end{array}$ & $\begin{array}{l}-0.000334 \\
(0.00118)\end{array}$ & $\begin{array}{l}-0.000815 \\
(0.00289)\end{array}$ & $\begin{array}{l}-0.00211 \\
(0.00751)\end{array}$ \\
\hline Employed & $\begin{array}{c}0.0342 * * \\
(0.0168)\end{array}$ & $\begin{array}{c}0.00829 * * \\
(0.00417)\end{array}$ & $\begin{array}{l}0.00325^{*} \\
(0.00172)\end{array}$ & $\begin{array}{l}-0.00152^{*} \\
(0.000900)\end{array}$ & $\begin{array}{c}-0.00452 * * \\
(0.00229)\end{array}$ & $\begin{array}{l}-0.0110^{* *} \\
(0.00549)\end{array}$ & $\begin{array}{c}-0.0286^{* *} \\
(0.0141)\end{array}$ \\
\hline Unemployed & $\begin{array}{l}0.0330 * \\
(0.0179)\end{array}$ & $\begin{array}{l}0.00800^{*} \\
(0.00441)\end{array}$ & $\begin{array}{l}0.00313^{*} \\
(0.00179)\end{array}$ & $\begin{array}{c}-0.00146 \\
(0.000934)\end{array}$ & $\begin{array}{l}-0.00436^{*} \\
(0.00242)\end{array}$ & $\begin{array}{l}-0.0107 * \\
(0.00578)\end{array}$ & $\begin{array}{l}-0.0276^{*} \\
(0.0151)\end{array}$ \\
\hline Asset Index & $\begin{array}{c}0.0136 * * * \\
(0.00508)\end{array}$ & $\begin{array}{c}0.00329 * * * \\
(0.00128)\end{array}$ & $\begin{array}{l}0.00129 * * \\
(0.000527)\end{array}$ & $\begin{array}{c}-0.000602 * * \\
(0.000284)\end{array}$ & $\begin{array}{c}-0.00180 * * * \\
(0.000696)\end{array}$ & $\begin{array}{c}-0.00438 * * * \\
(0.00168)\end{array}$ & $\begin{array}{c}-0.0114 * * * \\
(0.00428)\end{array}$ \\
\hline $\begin{array}{ll}\text { (Very) Good } \\
\text { financial }\end{array}$ & $0.0340 * *$ & $0.00825 * *$ & $0.00323 * *$ & $-0.00151 *$ & $-0.00450 * *$ & $-0.0110 * *$ & $-0.0285^{* *}$ \\
\hline & $(0.0147)$ & $(0.00360)$ & $(0.00145)$ & $(0.000773)$ & $(0.00195)$ & $(0.00471)$ & $(0.0124)$ \\
\hline $\begin{array}{l}\text { Very Good/Good } \\
\text { Health }\end{array}$ & $\begin{array}{l}0.109 * * * \\
(0.0141)\end{array}$ & $\begin{array}{l}0.0264 * * * \\
(0.00449)\end{array}$ & $\begin{array}{l}0.0103 * * * \\
(0.00225)\end{array}$ & $\begin{array}{c}-0.00482 * * * \\
(0.00163)\end{array}$ & $\begin{array}{c}-0.0144 * * * \\
(0.00251)\end{array}$ & $\begin{array}{c}-0.0351 * * * \\
(0.00514)\end{array}$ & $\begin{array}{c}-0.0910 * * * \\
(0.0123)\end{array}$ \\
\hline $\begin{array}{l}\text { (Fairly) easy to } \\
\text { walk a } 1 \mathrm{~K}\end{array}$ & $\begin{array}{l}0.103 * * * \\
(0.0242)\end{array}$ & $\begin{array}{l}0.0250 * * * \\
(0.00573)\end{array}$ & $\begin{array}{c}0.00977 * * * \\
(0.00247)\end{array}$ & $\begin{array}{c}-0.00456 * * * \\
(0.00176)\end{array}$ & $\begin{array}{c}-0.0136 * * * \\
(0.00329)\end{array}$ & $\begin{array}{c}-0.0332 * * * \\
(0.00768)\end{array}$ & $\begin{array}{c}-0.0861 * * * \\
(0.0201)\end{array}$ \\
\hline $\begin{array}{l}\text { (Fairly) easy to } \\
\text { climb stairs }\end{array}$ & $\begin{array}{c}0.0852 * * * \\
(0.0211)\end{array}$ & $\begin{array}{l}0.0207 * * * \\
(0.00591)\end{array}$ & $\begin{array}{c}0.00810 * * * \\
(0.00254)\end{array}$ & $\begin{array}{c}-0.00378 * * \\
(0.00148)\end{array}$ & $\begin{array}{c}-0.0113 * * * \\
(0.00325)\end{array}$ & $\begin{array}{c}-0.0275^{* * *} \\
(0.00730)\end{array}$ & $\begin{array}{c}-0.0714 * * * \\
(0.0180)\end{array}$ \\
\hline Observations & & & & 2,011 & & & \\
\hline
\end{tabular}



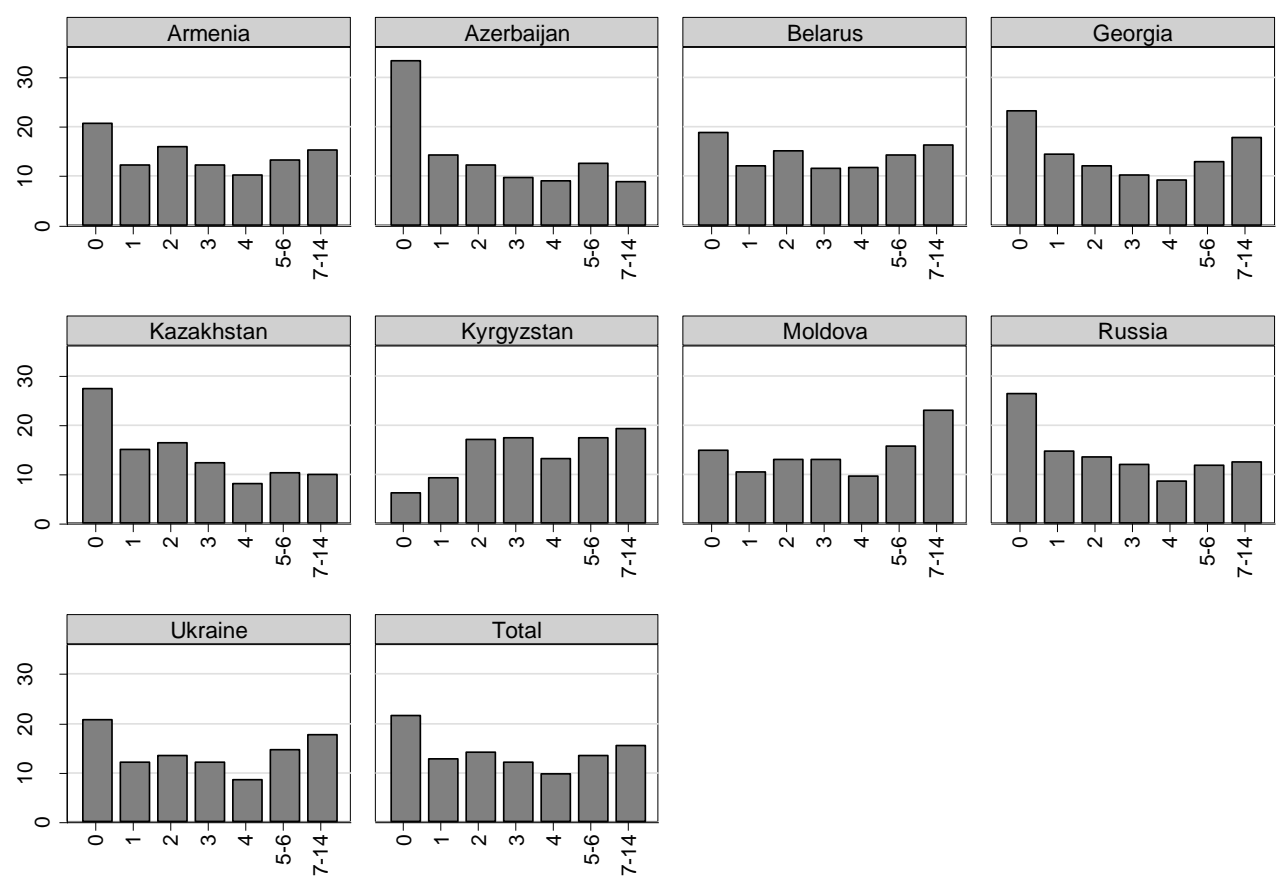

Mental health scores

Figure 1. Percentage plots of the collapsed mental health variable, by country
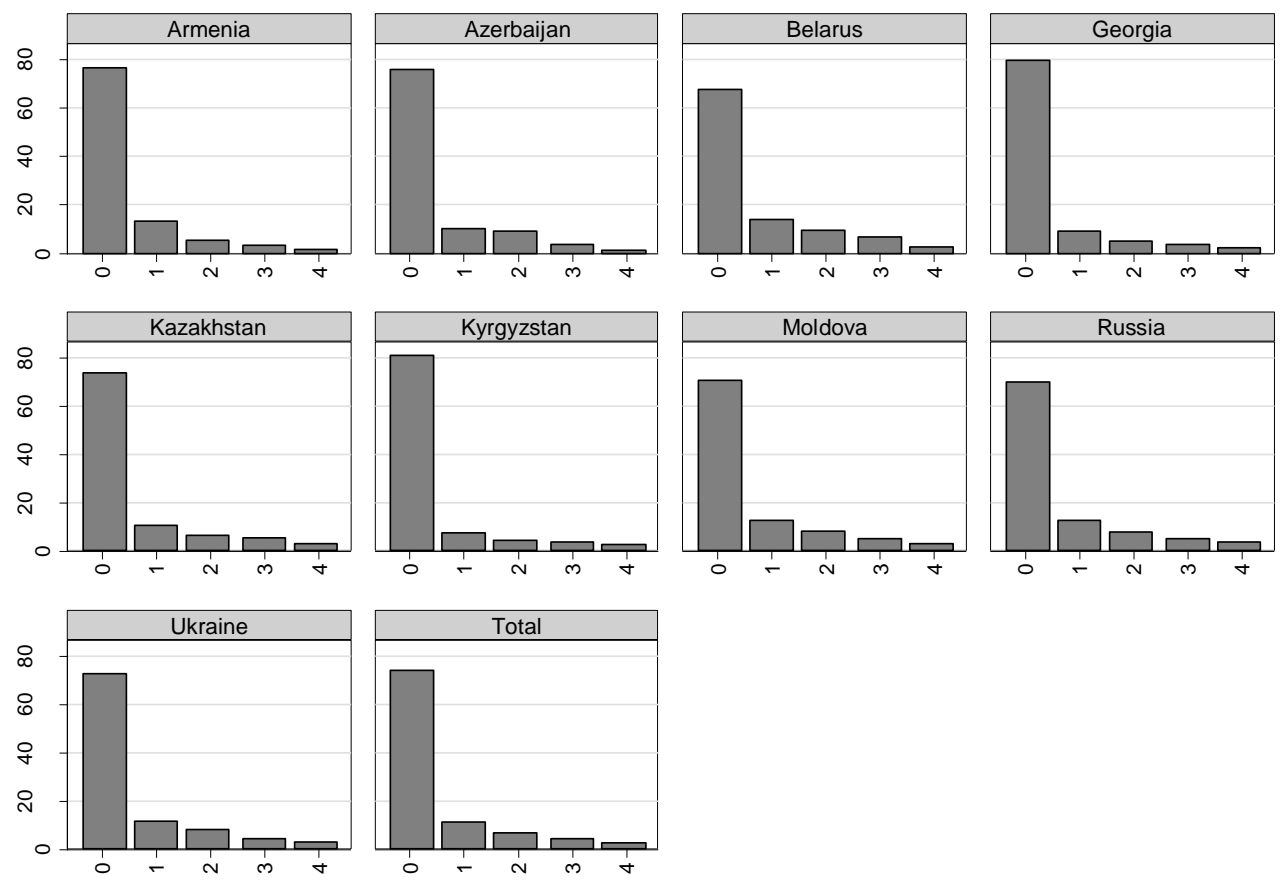

CAGE 0 to 4 scores

Figure 2. Percentage plots of the problem drinking instrument CAGE scores (problem drinking defined a value $\geq$ 2), by country. 

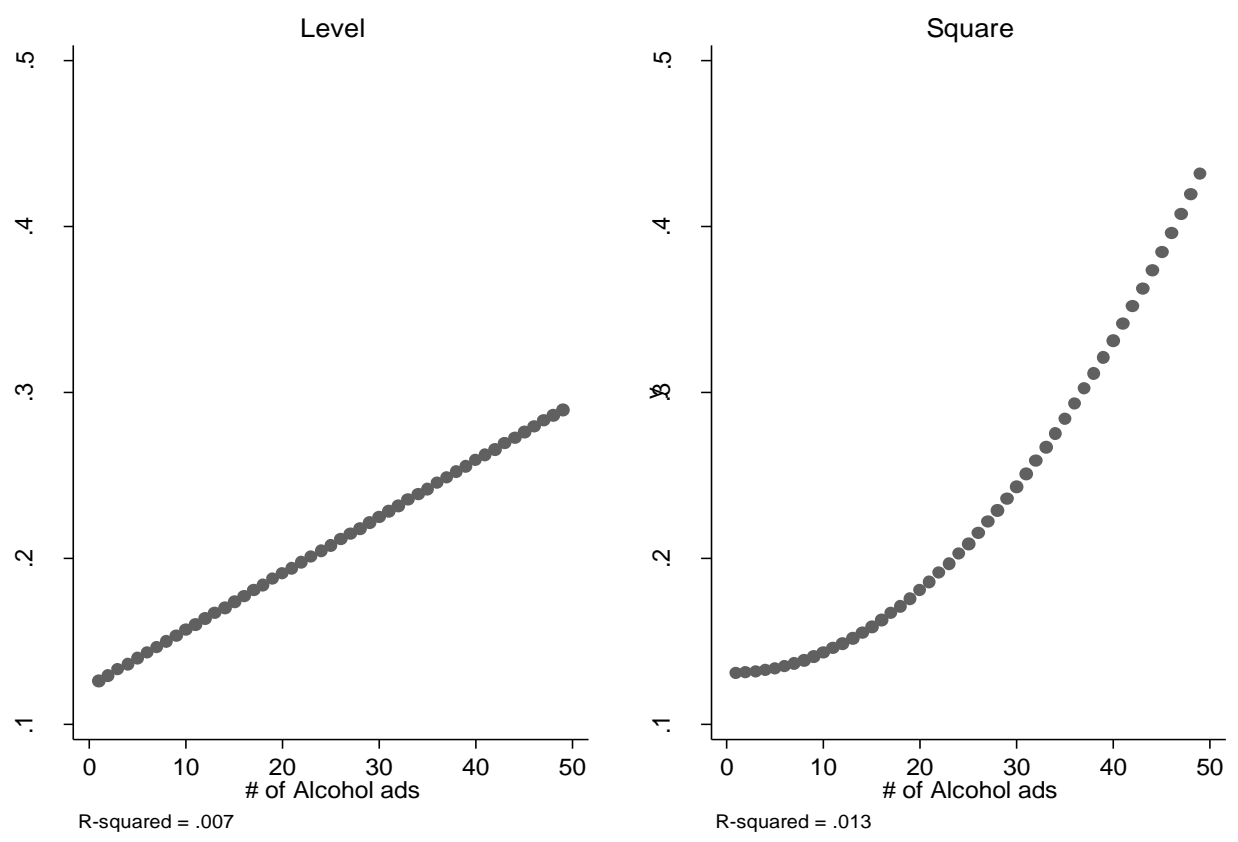

Figure 3. Comparison of the implied effects (from a linear probability model) of the level and squared number of alcohol advertisements on the probability of problem drinking. 